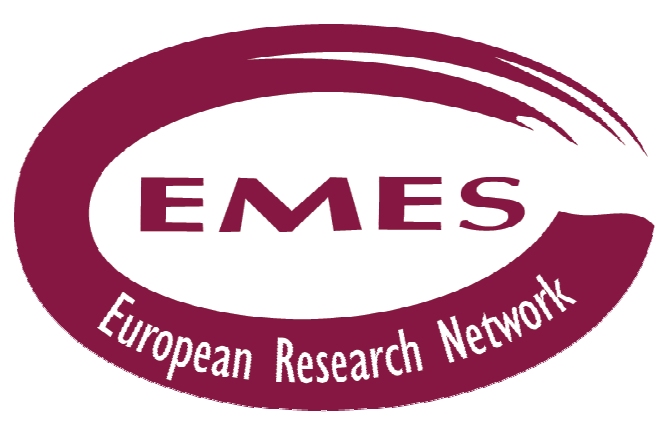

\title{
SOCIAL ENTERPRISE IN EUROPE: RECENT TRENDS AND DEVELOPMENTS
}

Jacques DEFOURNY

Marthe NYSSENS (eds.)

WP no. 08/01

with the collaboration of Karl Birkhölzer, Carlo Borzaga, Laurent Fraisse, Giulia Galera, Ewa Leś, Anne Liveng, Mary O'Shaughnessy, Pekka Pättiniemi, Heloísa Perista, Victor Pestoff, Roger Spear, Yohanan Stryjan and Flaviano Zandonai 


\section{TABLE OF CONTENTS}

SOCIAL ENTERPRISE IN EUROPE: INTRODUCTION TO AN UPDATE ............................. 4

SOCIAL ENTREPRENEUR, SOCIAL ENTREPRENEURSHIP, SOCIAL ENTERPRISE .................................. 4

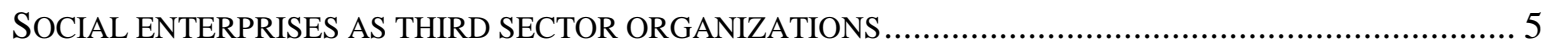

WORK INTEGRATION: A KEY FIELD OF ACTIVITY FOR EUROPEAN SOCIAL ENTERPRISES .................... 8

THE FUTURE OF SOCIAL ENTERPRISE BEYOND WORK INTEGRATION ............................................ 10

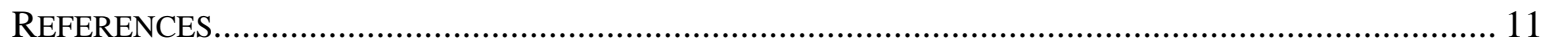

BELGIUM........................................................................................................................................................... 13

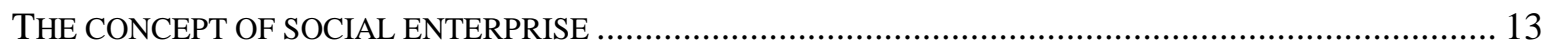

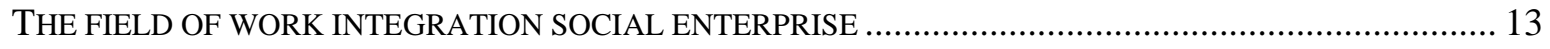

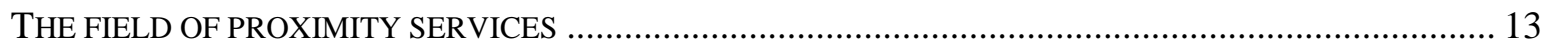

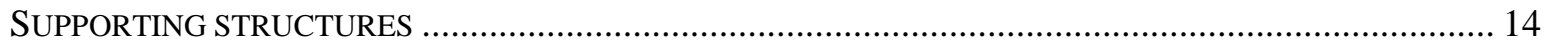

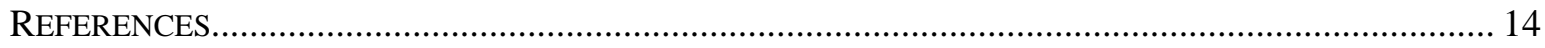

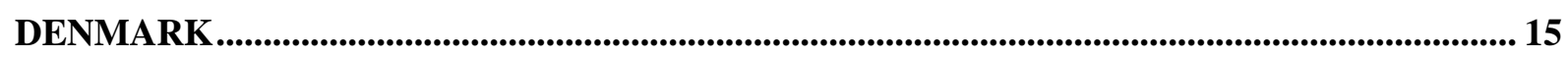

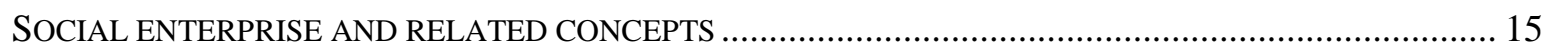

AREAS OF ACTIVITY OF SOCIAL ENTERPRISE AND SOCIAL ECONOMY ORGANIZATIONS …................ 15

SOCIAL ENTERPRISES, AT THE CROSSROADS OF THE THREE SECTORS ........................................... 15

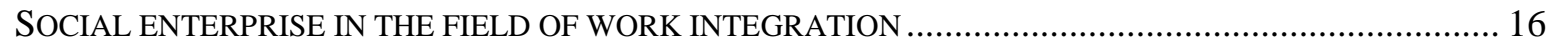

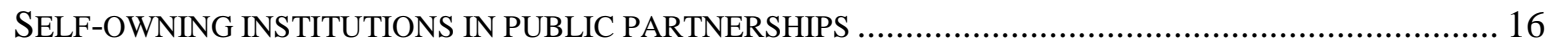

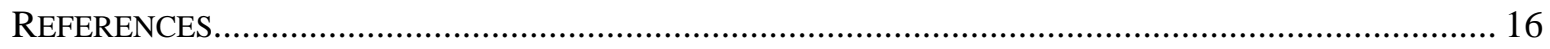

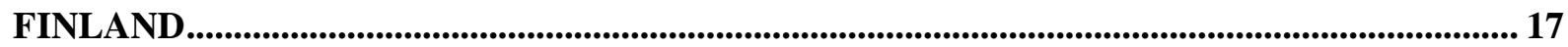

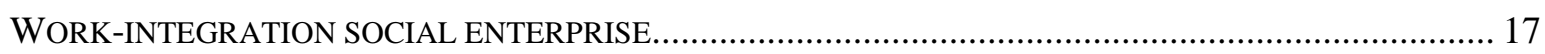

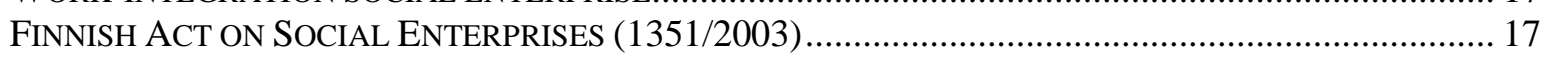

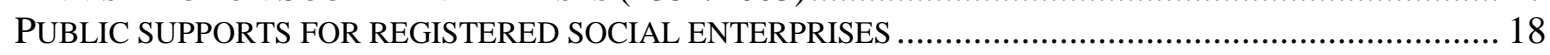

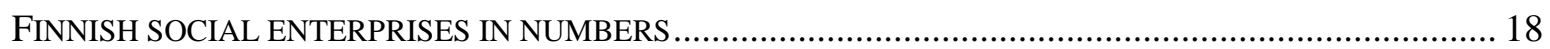

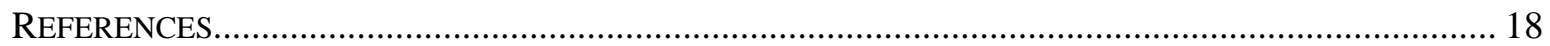

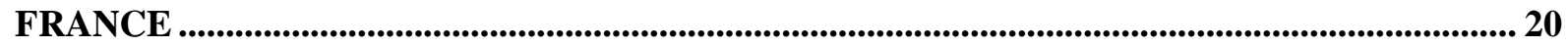

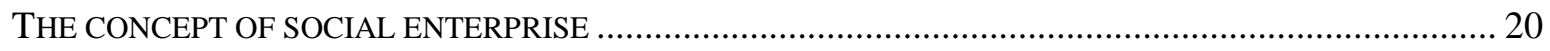

A NEW LEGAL STATUS, THE "COLLECTIVE INTEREST COOPERATIVE SOCIETY" ............................... 20

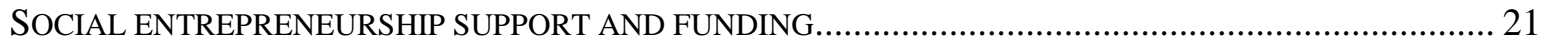

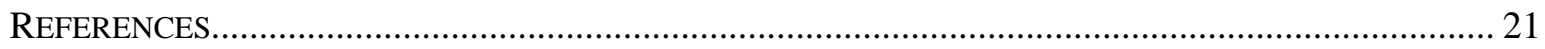

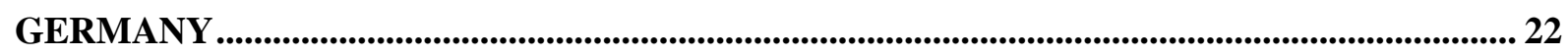

THE PARADOXICAL SITUATION OF SOCIAL ENTERPRISES IN GERMANY ............................................. 22

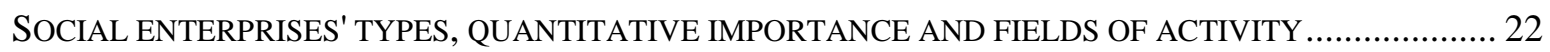

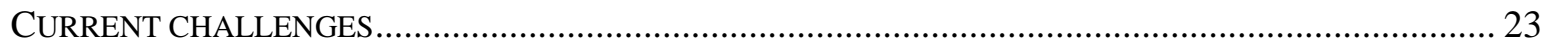

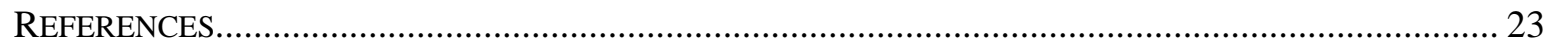

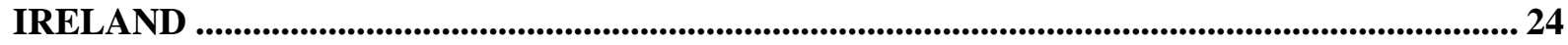

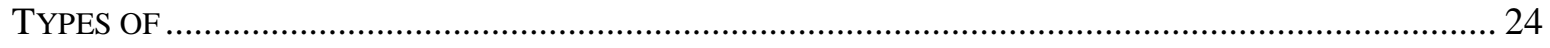

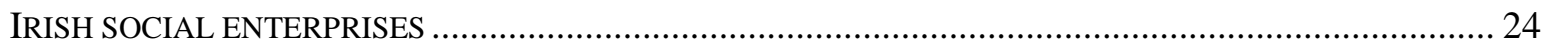

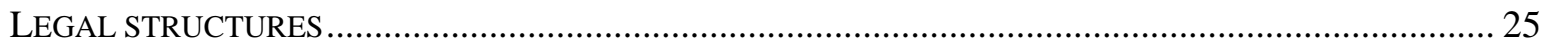

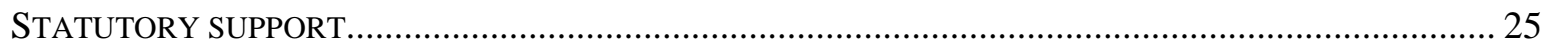

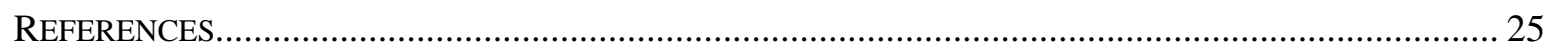

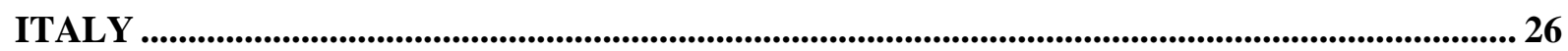

FROM SOCIAL COOPERATIVES TO A BROADER LEGAL CONCEPTION OF SOCIAL ENTERPRISE ........... 26

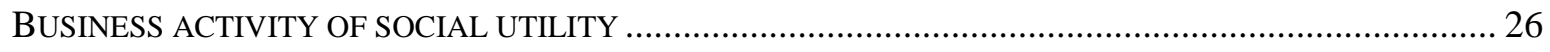

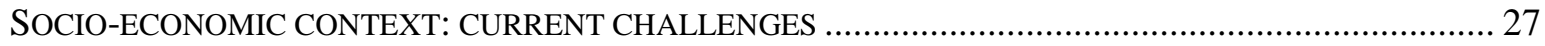




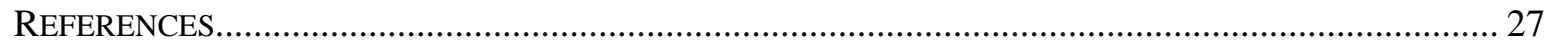

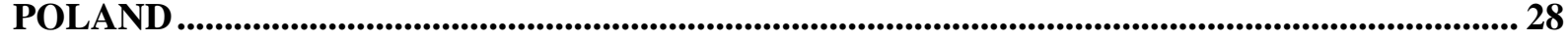

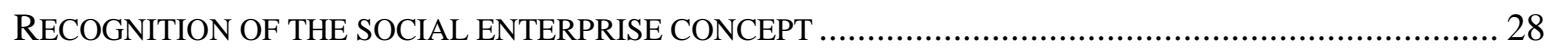

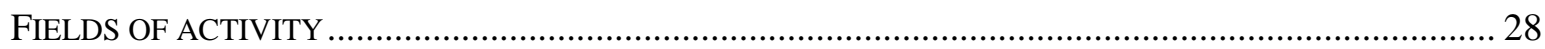

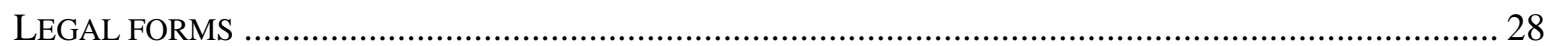

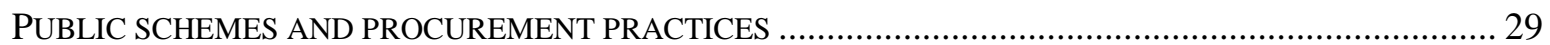

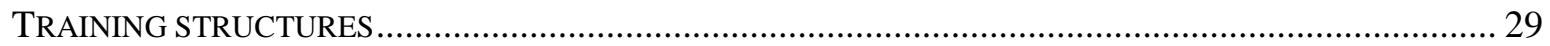

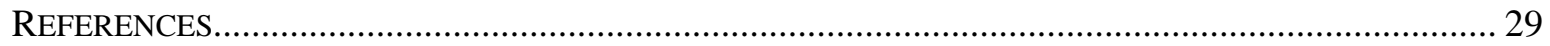

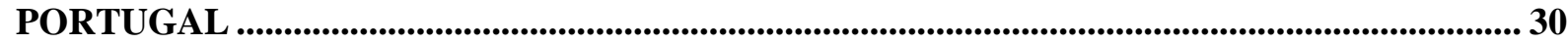

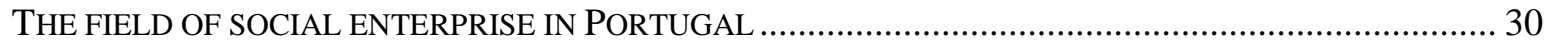

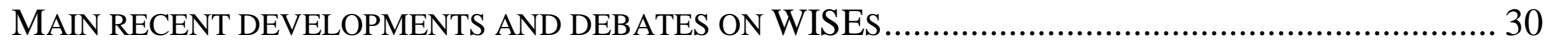

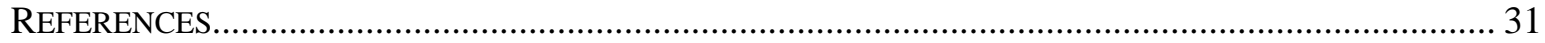

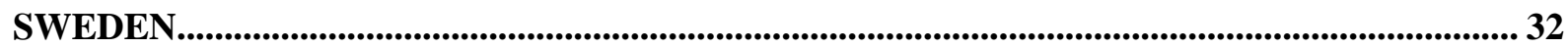

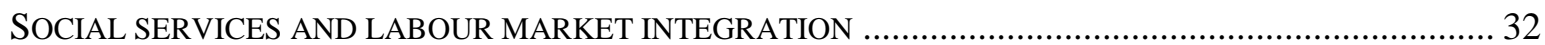

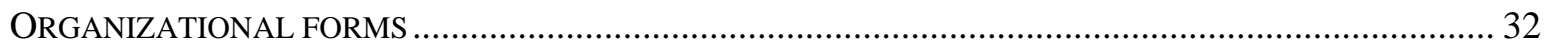

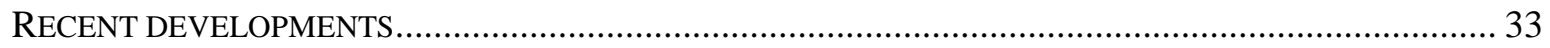

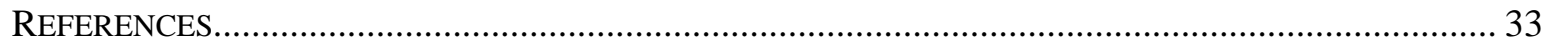

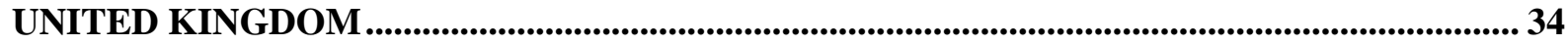

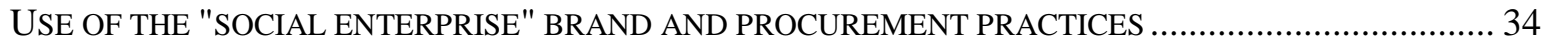

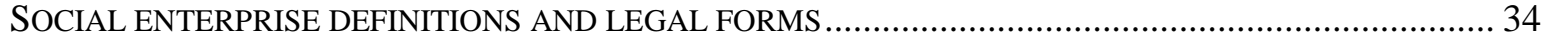

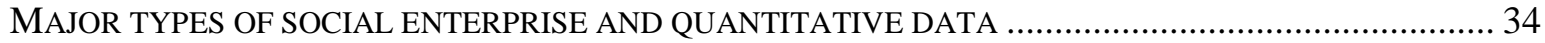

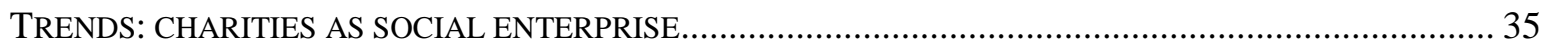

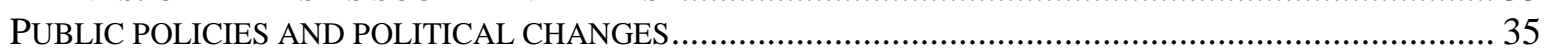

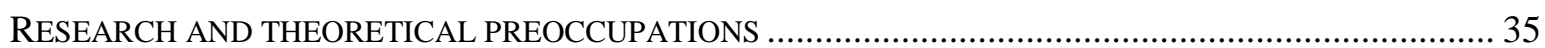

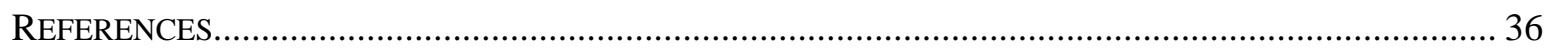

APPENDIX 1: THE EMES DEFINITION OF SOCIAL ENTERPRISE ........................................ 37 


\title{
SOCIAL ENTERPRISE IN EUROPE: INTRODUCTION TO AN UPDATE
}

\author{
Jacques Defourny \& Marthe Nyssens
}

Whereas a dozen years ago the concept of social enterprise was rarely discussed, it is now making amazing breakthroughs on both sides of the Atlantic, especially in EU countries and the United States. It is also attracting increasing interest in other regions such as Eastern Asia (especially Japan and South Korea) and Latin America.

The notion of social enterprise first appeared in Italy in the late 1980s, but it really began to be used at the European level in the mid 1990s, especially through the works of the EMES European Research Network ${ }^{1}$. As will be shown in the following pages, although the concept itself has not gained the same recognition in all European countries (and is even still poorly understood in several of them), the field realities that it aims to highlight are developing almost everywhere and increasing research efforts are being made to analyse them.

International literature on this theme is thus now developing significantly. Within this context, the objective of the present paper is twofold: first, through this introductory part, we try to synthesize major evolutions experienced by social enterprises across Europe and key challenges they are facing; in the second part, members of the EMES Network provide a more precise - although concise - update as to current trends and debates in their respective countries. ${ }^{2}$ But before going further, it seems useful to begin with some terminological clarifications.

\section{Social entrepreneur, social entrepreneurship, social enterprise}

Until recently, the notions of "social entrepreneur", "social entrepreneurship" and "social enterprise" were used more or less along the same lines: simplifying a little, one could say that social entrepreneurship was seen as the process through which social entrepreneurs created social enterprises. In the last decade, however, a fast growing literature has produced various definitions and approaches of each of these three notions. A detailed analysis of these different approaches is clearly beyond the scope of the present work, but a few features may be pointed out in order to stress some current trends:

- The term "social entrepreneur" has been particularly emphasized by American foundations and organizations like Ashoka since the mid 1990s. Those entities identify and support in various ways individuals launching new activities dedicated to a social mission while behaving as true entrepreneurs in terms of dynamism, personal involvement and innovative practices. Such a social entrepreneur brings about new ways of responding to social problems. In Europe, on the contrary, the emphasis has been much more often put on the collective nature of the social enterprise, as well as on its associative or cooperative form, although the US approach is gaining some influence.

- The notion of "social entrepreneurship" has been conceptualized in rather precise ways in the late $1990 \mathrm{~s}^{3}$. These conceptualisations stress the social innovation processes undertaken by social entrepreneurs. However, the concept is increasingly being used in a very broad sense as, for various authors, it now refers to a wide spectrum of initiatives, ranging from voluntary activism to corporate social responsibility ${ }^{4}$. Between these two extremes, a lot of categories can be

\footnotetext{
${ }^{1}$ These research works, mainly supported by the European Commission's Research Directorate-General, resulted in a first book entitled The Emergence of Social Enterprise (Borzaga and Defourny 2001), a wide series of EMES Working Papers (available on www.emes.net) and, more recently, a second book, edited by Nyssens (2006), focusing on work integration social enterprises. The EMES Network has also extended its research area to Eastern and Central European countries, including some countries of the Community of Independent States, such as Ukraine (Borzaga and Spear 2004; EMES 2006).

${ }^{2}$ Contributions to this joint paper were first prepared for an EMES Members' Seminar in Barcelona, in December 2006. They were then discussed and revised during the year 2007.

${ }^{3}$ Especially by Dees (1998) and by the EMES Network (EMES 1999; further developed by Defourny 2001).

${ }^{4}$ See for instance Nicholls (2006).
} 
identified: individual initiatives, non-profit organizations launching new activities, publicprivate partnerships with a social aim etc. While Americans now tend to stress the "blurred boundaries" among institutional and legal forms as well as the "blended value creation" (profits alongside social value) that characterizes social entrepreneurship, Europeans rather stress the fact that social entrepreneurship most often takes place within the "third sector" (i.e. the private, not-for-profit sector). In any case, it seems clear that, of the three notions briefly defined here, that of "social entrepreneurship" is the most encompassing one.

- As to the concept of "social enterprise", it first appeared in Europe (a few years before it emerged in the United States), and more precisely in Italy, where it was promoted by a journal launched in 1990 and entitled Impresa sociale. The concept was introduced at the time to designate the pioneering initiatives for which the Italian Parliament created the legal form of "social cooperative" one year later. As will be shown, various other European countries have since passed new laws to promote social enterprises. Along with such approaches, the EMES Network stresses the positioning of European social enterprises "at the crossroads of market, public policies and civil society"5, especially to underline the "hybridization" of their resources: social enterprises indeed combine income from sales or fees from users with public subsidies linked to their social mission and private donations and/or volunteering. This clearly contrasts with a strong US tendency to define social enterprises only as non-profit organizations more oriented towards the market and developing "earned income strategies" as a response to decreasing public subsidies and to the limits of private grants from foundations ${ }^{6}$.

While being aware of the conceptual diversity that we have just underlined, we mainly focus here on the notion of social enterprise as developed by the EMES Network through a permanent dialogue among researchers from all parts of the European Union, representing various social, political and economic "traditions". The conceptualization of social enterprise developed by the Network is based on four economic criteria and five social criteria ${ }^{7}$. Those criteria, however, do not represent a set of conditions that an organisation should meet to qualify as a social enterprise; indeed, rather than constituting prescriptive criteria, these indicators describe an "ideal-type" (in Weber's terms) that enables researchers to position themselves within the "galaxy" of social enterprises. In such a perspective, they constitute a tool, somewhat analogous to a compass, which can help anyone to locate the position of the observed entities relative to one another and maybe to establish the boundaries of the set of organisations that he or she will consider as that of social enterprises.

For the purpose of the present overview, we may summarize the EMES definition as follows: "Social enterprises are not-for-profit private organizations providing goods or services directly related to their explicit aim to benefit the community. They rely on a collective dynamics involving various types of stakeholders in their governing bodies, they place a high value on their autonomy and they bear economic risks linked to their activity".

\section{Social enterprises as third sector organizations}

Within the terminological landscape described in the previous section, it is possible to argue that some forms of social entrepreneurship may be found in the private for-profit sector and the public sector. However, as far as social enterprises are concerned, the different approaches across Europe locate them, mainly, within the third sector or the social economy, understood as embracing non-profit organizations as well as co-operatives and related not-for-profit private forms of enterprises.

\section{From the pioneering Italian experience to the British policy promoting social enterprise}

In the late 1980s, new co-operative initiatives emerged in Italy to respond to unmet needs, especially in the field of work integration, as some groups were increasingly excluded from the labour market, as well as in the field of personal services, in a context of rapid aging of the population and changes in family structures. In contrast to traditional co-operatives who were primarily oriented toward members' interests, these initiatives were serving a broader community and putting more emphasis on

\footnotetext{
${ }^{5}$ This is precisely the subtitle of the latest EMES book (Nyssens 2006).

${ }^{6}$ See for instance Dees and Anderson (2006).

${ }^{7}$ These criteria are presented in Appendix 1.
} 
the dimension of general interest ${ }^{8}$. They also differed from traditional co-operatives in that they often combined different types of stakeholders in their membership (paid workers, volunteers and other supporting members, etc.), whereas traditional cooperatives are usually single-stakeholder organizations. In 1991, the Italian Parliament adopted a law creating a specific legal form for these "social solidarity co-operatives" - which were subsequently renamed "social co-operatives". The law distinguishes between two types of social co-operative: those delivering social, health and educational services, called "A-type social co-operatives" (cooperative sociali di tipo a), and those providing work integration for disadvantaged people, referred to as "B-type social co-operatives" (cooperative sociali di tipo b). In 2005, there were more than 7,300 social co-operatives in Italy; they employed some 244,000 workers.

This impressive development of social co-operatives has not prevented other types of Italian third sector organizations from developing social entrepreneurial activities; consequently, a broader law on social enterprise (impresa sociale) has been adopted in 2005. This law crosses the boundaries of legal forms, enabling various types of organizations (not only co-operatives and non-profit organizations, but also investor-owned organizations, for instance) to obtain the "legal brand" of social enterprise, provided that they comply with the non-distribution constraint and organize the representation of certain categories of stakeholders, including workers and beneficiaries. This law on social enterprise identifies a wide range of activities defined as fields of "social utility": welfare services, work integration, environmental services, health, education... However, up to now, very few organisations have adopted this new legal brand as it does not so far involve any concrete advantage.

More than a decade after Italy gave the first impetus to the social enterprise concept, the UK government defined social enterprises as "businesses with primarily social objectives whose surpluses are principally reinvested for that purpose in the business or in the community, rather than being driven by the need to maximize profit for shareholders and owners" (DTI 2002). Social enterprises can tackle a wide range of social and environmental issues and operate in all parts of the economy. In 2005 , it was estimated that there were some 15,000 social enterprises in the country, although there is concern about the validity of these data, as the suggested definition does not provide clear-cut criteria to identify such organisations ${ }^{9}$. A Social Enterprise Unit was created in the Department of Trade and Industry to support their development. In 2006, this unit was transferred to the Cabinet office, where it is now linked with government responsibilities for the voluntary sector within the "Third Sector Office". Moreover, a new legal form, the "Community Interest Company" (CIC), was approved by the British Parliament in 2004. The CIC legal form includes a community interest test and an asset lock to ensure that the new entity is dedicated to its expressed community purposes. The 1,000th community interest company was created less than 2 years after the implementation of this legal form.

Both in Italy and in UK, social enterprises are thus embedded in the third sector. They are defined by their social purpose and the limitation on the distribution of profit that they impose upon themselves. In both countries too, social enterprises are active in a wide spectrum of activities. However, these two models also differ in some aspects. While the Italian laws stress a specific governance model, through a requirement to involve various stakeholders, the British model stresses the business character of social enterprise: although no reference is made to the percentage of market resources in the definition, it is widely accepted that a significant part (usually 50\%) of the total income must be market-based for the enterprise to qualify as "social enterprise".

\section{New legal forms reflecting social enterprise dynamics within the social economy}

Between the adoption of the Italian law, in 1991, and the implementation of the British one, in 2004, other European countries introduced new legal forms reflecting the entrepreneurial approach adopted by an increasing number of "not-for-profit" organizations, even though the term of "social enterprise" was not always used as such.

\footnotetext{
${ }^{8}$ In the 1980s, initiatives in the same fields also appeared in various other countries, but they could often be seen as an evolution of traditional associative or non-profit sector organizations toward a more productive role.

${ }^{9}$ One year later, it was suggested that 55,000 organizations might meet the criteria of the definition (Office of the Third Sector, 2006).
} 
In France, Portugal, Spain and Greece, these new legal forms are of the co-operative type. The Portuguese "social solidarity co-operative" (cooperativa de solidariedade social) legal form was created in 1997. This type of co-operative provides services with an objective to foster the integration of vulnerable groups, such as children, people with disabilities and socially disadvantaged families and communities. Portuguese social solidarity co-operatives combine in their membership users of the services, workers and volunteers; they cannot distribute any profit to their members. As for Spain, a national law created the label of "social initiative co-operative" (cooperativa de iniciativa social) in 1999; any type of co-operative providing social services or developing an economic activity aiming at the work integration of socially excluded persons can use this label. Twelve autonomous regions have since developed their own legislation linked to this national law. As their Portuguese counterparts, Spanish social initiative co-operatives cannot distribute any profit, but their organizational forms are usually less oriented to a multi-stakeholder structure than what is the case in some other European countries.

On this last point, however, it is worth underlining that empirical research has shown that the singlestakeholder character does not seem to jeopardize the multiple-goal nature of social enterprises; the latter can have governing structures made of a single stakeholder category, as it is the case in many traditional co-operatives, and still pursue the satisfaction of the needs of the community at large or of particular disadvantaged groups (Campi et al. 2006). This suggests once more that the borders of the social enterprise phenomenon are not clear-cut ones.

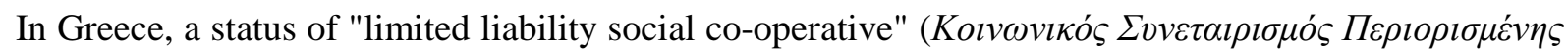

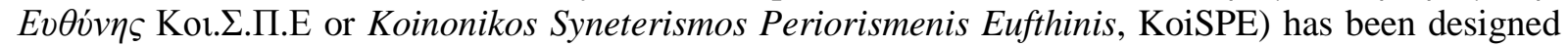
in 1999 for organizations targeting very specific groups of individuals with psycho-social disabilities and aiming at the socio-professional integration of the latter through a productive activity. These organizations are based on a partnership between individuals of the "target group", psychiatric hospital workers and institutions from the community. Such a multi-stakeholder strategy is also at the heart of the French law, passed in 2002, which defines the "collective interest co-operative society" (société coopérative d'intérêt collectif, or SCIC). Indeed, this new form of co-operative undertaking brings together employees, users, volunteers, local and regional authorities and any other partner wishing to work together on a given local development project.

In Belgium, the "social purpose company" (société à finalité sociale, or SFS, in French; vennootschap zonder winstoogmerk, or VSO, in Dutch) legal framework, introduced in 1996, does not focus on the sole co-operative tradition, although it is often combined with the latter. More precisely, this framework is not, strictly speaking, a new legal form, as all types of business corporations can adopt the "social purpose company" label, provided they "are not dedicated to the enrichment of their members". Therefore, the company must define a profit allocation policy in accordance with its social purpose and provide for procedures allowing each employee to participate in the enterprise's governance through the ownership of capital shares.

In France and Belgium, these legal innovations have met, up to now, with little success. This may be explained by the fact that they involve a considerable number of requirements which add to those associated with traditional legal forms, without bringing a real value added for the concerned organizations. Unlike the concepts of social economy or solidarity-based economy, which have inspired coalitions of actors for the last twenty years, from both the world of associations and that of co-operatives, and which are increasingly characterised by a social entrepreneurial approach, the notion of social enterprise itself is far from having achieved general recognition in these two countries.

\section{A variety of other legal forms adopted by social enterprises}

Although newly created legal forms may prove to be important tools in some countries, most social enterprises across Europe, even in countries where these new legal forms have emerged, still adopt legal forms that have existed for a long time, namely those of association, co-operative, company limited by guarantee or by share, Industrial and Provident Societies in the UK etc. More generally, social enterprises are often established as associations in those countries where the legal form of association allows a significant degree of freedom for selling goods and services. In countries where 
associations are more limited in this regard, social enterprises are set up, more often, under the legal form for co-operatives. And in some cases, social enterprises adopt traditional business legal forms.

In some European countries, the concept of social enterprise is not part of the political agenda nor of the academic discourse outside a very small circle of experts; this is in particular the case in Germany. The main reason for this probably lies in the fact that the German socio-economic model is based on a wide social partnership agreement around the concept of "social market economy", understood as a specific articulation between the market and the state to foster socio-economic development. Within such a model, the specific roles of social enterprises - or the social economy as a third sector - are particularly difficult to highlight. Although there exist plenty of not-for-profit organizations characterized by an entrepreneurial approach and addressing emerging social needs, these organizations are not considered as making up a distinct group; they seem to be "split up" in a variety of different "milieus", each with its own identities.

\section{Work integration: a key field of activity for European social enterprises}

Social enterprises may be active in a wide spectrum of activities, as the "social purpose" may refer to many different fields. However, one major type of social enterprise is clearly dominant across Europe, namely "work integration social enterprises" (WISEs) (Nyssens 2006). Indeed, the persistence of structural unemployment among some groups, the limits of traditional active labour market policies and the need for more active and innovative integration policies have naturally raised questions concerning the role that social enterprises could play in combating unemployment and fostering employment growth. Precisely, the main objective of work integration social enterprises is to help low qualified unemployed people, who are at risk of permanent exclusion from the labour market. WISEs integrate these people into work and society through a productive activity. In a number of European countries, the development of specific public schemes targeted at this type of social enterprise has even led to the concept of social enterprise being systematically associated with such employment creation initiatives.

\section{Social enterprise within labour market policy debates}

The Finnish Act on Social Enterprise (2003) is emblematic of such a trend, as it reserves this term to the field of work integration. According to this Act, a social enterprise, whatever its legal status, is a market-oriented enterprise created for employing people with disabilities or long-term unemployed (it has to be noted that, probably due to the limited extent of benefits linked hereto, only very few organisations in Finland have decided to register as social enterprises so far - around 70 as of the end of 2007). In 2006, Poland also passed an Act on Social Co-operatives, specifically intended for the work integration of particular needy groups (such as ex-convicts, long-term unemployed, disabled persons and former alcohol or drug addicts). And Spain's national Parliament has just voted a law on work integration enterprises (in December 2007). It should be noted that these different legislations do not define any new legal form; they rather create a tool like an official register for social enterprises.

In several other European countries, even when the term of social enterprise is still relatively absent, both from mainstream policy and scientific debate, it also appears, when used, as associated with the issue of active labour market policies. In Portugal, for instance, there is an on-going debate about the role of third sector organisations when they support the creation of integration companies (empresas de inserção) in the "social employment market", which aims to reintegrate disadvantaged persons through work. In Sweden, the term "social co-operative" (sociala kooperativ) has become synonymous with "work integration social enterprise", even though the Swedish landscape is also characterized by the development of social entrepreneurial dynamics in the field of personal services, for example under the form of parent or worker co-operatives and voluntary (commonly multi-stakeholder) associations. Social enterprise as a concept is just about to enter Danish discourse on social cohesion (Hulgård and Bisballe 2004), but it has primarily been used so far as part of an active labour market policy, with an ambition to make traditional enterprises - and especially small and medium enterprises (SMEs) - more socially responsible in matters of integration of unemployed persons into the labour market. 


\section{Public schemes targeting work integration social enterprises: advantages and risks}

In many countries, besides the creation of new legal forms or frameworks, the 1990s have seen the development of specific public programs targeting social enterprise, most of them in the field of work integration ${ }^{10}$. Examples of public programs at the national level include those promoting integration enterprises (empresas de inserção) in Portugal, integration enterprises and intermediary associations (entreprises d'insertion and associations intermediaires, respectively) in France, and the alreadymentioned social enterprises (sosiaalinen yritys) in Finland, as well as the Social Economy Program in Ireland. At the regional level, there are public programs focusing on work-integration enterprises (entreprises d'insertion), on-the-job training enterprises (entreprises de formation par le travail) and social workshops (sociale werkplaatsen) in Belgium and on work-integration enterprises (empresas de inserción) in Spain.

Indeed, WISEs have increasingly represented a tool for implementing active labour market policies. In several countries, they have really become a "conveyor belt" of such policies. In France, for instance, 2,300 registered structures were providing work-integration services through public schemes and employed some 220,000 salaried workers in 2004. On the other hand, one should not forget that WISEs were pioneers in promoting the integration of excluded persons through a productive activity, and in many contexts, it can even be said that the first WISEs actually implemented active labour market policies before the latter came into institutional existence.

The recognition, by public authorities, of the mission of work integration performed by social enterprises allows the latter, in most cases, to access public subsidies that - even though they remain limited - are more stable. However, these subsidies are often only temporary; they are usually granted to launch an initiative and to compensate for the "temporary unemployability" of the workers. Such measures are in fact intended only to facilitate the transition from unemployment to the "first" labour market. In some cases (like under the Finnish Act), social enterprises are only eligible to active labour programs just as any other type of enterprise hiring employees with the required profiles.

While recognising and supporting WISEs, public policies also influence the objectives of these organisations, which may change over time through a process of institutionalisation. This appears clearly when analyzing the philosophy of the innovative social enterprises which emerged in the 1980s. The key issue then was the empowerment and integration of excluded groups through their participation in enterprises whose aim was to offer disadvantaged workers a chance to reassess the role of work in their lives and to recover control over their own personal project. Such a conception implied not only giving an occupation to these persons, but also developing specific values, for example through democratic management structures in which the disadvantaged workers were given a role, and/or through the production of goods and services generating collective benefits (such as social services or services linked to the environment) for the territory in which these social enterprises were embedded. Getting workers back into the "'first" labour market was thus not the priority of these pioneering WISEs. However, the progressive institutionalization and professionalization of the field over the years, through public schemes increasingly linked to active labour market policies, generated strong pressures to make the social mission instrumental to the integration of the disadvantaged workers into the labour market. This explains why some pioneering initiatives chose not to use WISEspecific public schemes; this is for example the case of the "local development" initiatives in Ireland, which did not make use of the "social economy" framework (O'Shaughnessy 2006a). Indeed, although local development initiatives originated prior to the implementation of the national Social Economy Programme which in effect gave rise to social economy WISEs, their reluctance to avail of national social economy programme funding is more related to two reasons: (1) local development WISEs were already benefiting from one type of active labour market policies (ALMP) namely Community Employment and (2) the conditions of entry for national social economy programme funding were quiet strict, in particular the priority that was placed on the social enterprise to become financially viable within a three year period (O'Shaughnessy 2006b). It should be noted too that, while public schemes have encouraged some initiatives, they sometimes excluded others such as some WISEs characterized by a self-help dynamic in France.

\footnotetext{
${ }^{10}$ Those public programs sometimes impose a specific legal form to be eligible. In other cases, they do not do so.
} 


\section{The future of social enterprise beyond work integration}

\section{A widening range of activity fields}

Although the work integration of disadvantaged people is often seen in Europe as a major field for social enterprises, the latter also experienced a significant development in a wide range of other areas. For instance, from the early 1990s, Italian "A-type" social co-operatives, providing social and personal services, underwent a rapid development and hired thousands of highly skilled professionals in the fields of health care, psychology, mental health care and training. Indeed, the number of enterprises and jobs created in such services has always been much larger than in "B-type" (work integration) social co-operatives.

In Sweden and in France, childcare services are clearly a major field of activity for social enterprises, which are often set up and managed by parents and professionals as a response to a public provision shortage (Fraisse et al. 2007). The same can be said of the UK, which also witnesses a fast growth of social enterprises in social housing and home care services, as well as in a wide spectrum of community and social services, including culture, arts and sports. In Belgium and France, the so-called "proximity services" refer to a variety of personal or collective services offered by social enterprises.

In some countries, like Ireland, the emphasis is put on the role of social enterprises and the social economy in local development. A similar trend may be observed in Greece, where agro- tourist cooperatives are being set up in remote areas, mostly by women.

When looking at new legal frameworks, it appears clearly that the French "collective interest cooperative society", the Portuguese "social solidarity co-operative", the Belgian "social purpose company" and the Spanish "social initiative co-operative" are not especially designed for work integration enterprises; the provision of social services is at the heart of the Spanish and Portuguese laws. Even in countries such as Finland and Poland, where current legislations on social enterprises or social co-operatives only focus on work integration, new fields of activity, such as social and community services, are emerging.

In the same line, the Italian law on social enterprise which was passed in 2005 opens up explicitly new fields of "social utility", such as environmental and eco-system protection, cultural heritage and cultural services, social tourism, research activities and education.

Given all those developments, one might reasonably expect a diversification of social enterprises' activities throughout the European Union, including in new member states.

\section{Public contracts and other public policies}

The contracting out of the provision of goods or services is a key channel for public authorities to support the mission of social enterprises. Indeed, empirical analysis highlights the importance of the sales of social enterprises to local public bodies (Laville et al. 2006).

Under certain thresholds defined by European legislation, public bodies (usually at the local level) may simply "privilege" social enterprises they know in order to support the latter and their social mission; in the case of purchases over these threshold amounts, specific rules have to be respected, but these rules do not exclude the possibility to take into account social dimensions in the procedures for the award of public contracts. Indeed, two different types of award criteria are allowed: public authorities can award a contract to the tender with "the lowest price" (i.e. the bid with the lowest price, for the required level of quality, is chosen) or they can choose to award the contract to "the most economically advantageous tender", i.e. take into consideration criteria other than price alone (such as social or environmental criteria) in their purchasing decision. They can for example introduce social clauses regarding the integration of disadvantaged workers or a requirement to make services available for specific target groups or communities. ${ }^{11}$ However, the practice of inserting social criteria into

\footnotetext{
${ }^{11}$ On the subject of the inclusion of criteria other than the price alone in public procurement, see Navez, F. (2005) "Marchés publics et évolution du droit européen : Quelles possibilités de soutien. pour les entreprises d'économie sociale ?" Presented at the 1st EMES-ISTR European conference, Paris, April 2005. Available at: http://www.emes.net
} 
public contracts is not yet very common in the European Union. Italy provides the oldest example of such practices: as soon as 1991, a law was passed in this country to reserve certain public contracts to social co-operatives. Although this law had to be re-designed following objections from the European Commission alongside its competition policy, such a possibility has been maintained and remains a key tool. Debates about this kind of issue are still going on today at the European level. ${ }^{12}$

In many countries, the legal framework regulating public procurement is less favourable to social enterprises than in Italy. For instance, the tender regime implied by the Swedish Law on Public Procurements prevents authorities from considering social factors; the Swedish interpretation of EU public procurement legislation does not allow for preferred treatment for social enterprises. The same situation prevails in Ireland, the United Kingdom, Portugal and Spain. But legislation is evolving in other countries (such as Belgium), which are considering introducing social clauses into public tenders. Indeed, national and regional practices in this matter are relatively diverse across the European Union. Competing in the market with for-profit companies solely on the basis of financial criteria often appears difficult for social enterprises, which often support costs that are externalized by traditional companies, and some of them therefore request that public authorities take their social dimension into account when awarding public contracts. This is clearly an important debate for the future of social enterprises across Europe.

Another channel that opens a space for social enterprises is the development of voucher systems, wherein the consumer can choose the provider. Such systems are usually open to a broad set of providers - public, for-profit private and not-for-profit providers - and put them in a situation of competition on a quasi-market. This is the case of the voucher systems which have recently been introduced in the field of domiciliary care in France and Belgium. In a context where the services industry - and more specifically personal services - is "on the rise", the development of these services generates high expectations, based on the collective benefits they can produce (impact in terms of equity among users, creation of high-quality jobs). Therefore, it is important that the question of the value added of social enterprise models - which are driven by their explicit aim to benefit the community - be studied more thoroughly.

Is the development of social enterprise in the field of services a sign of a retrenchment of the welfare state or, on the contrary, a way to enhance the collective benefits that may be associated with these services? The answer is obviously complex. Previous EMES works suggest that the response will vary depending on the type of public regulation which is developed (Spear and Bidet 2003; Nyssens 2006). If public authorities limit their action to developing quasi-market policies and place all types of providers on an equal contractual footing, without taking into account the collective benefits that the providers create, the risk exists that the social innovation role of social enterprises will be curtailed, as most probably will be their capacity to provide specific answers to these collective problems. Conversely, if public bodies recognise the specific features of social enterprise models and foster their development, social enterprises could make their specific contribution to the public good.

\section{References}

Borzaga, C. \& Defourny, J. (eds) (2001) The Emergence of Social Enterprise, London and New York: Routledge (paperback edition: 2004).

Borzaga, C. \& Spear, R. (2004) Trends and Challenges for Co-operatives and Social Enterprises in Developed and Transition Countries, Trento: Edizioni31.

Campi, S., Defourny, J. \& Grégoire, O. (2006) "Work Integration Social Enterprises: Are they Multiple-Goal and Multi-Stakeholder Organizations?" in Nyssens, M. (ed.) Social Enterprise, London \& New York: Routledge, 29-49.

CECOP (2006) Social enterprises and worker cooperatives: Comparing models of corporate governance and social inclusion, CECOP European Seminar, Manchester, November 9, 2006.

Davister, C., Defourny, J. \& Grégoire, O. (2004) "Les entreprises sociales d'insertion dans l'Union Européenne : un aperçu général", Revue des Etudes Coopératives, Mutualistes et Associatives

\footnotetext{
12 More broadly, the access to specific public supports is at the very heart of discussions about "social services of general interest".
} 
(RECMA), no 293, pp. 24-50. (English and French versions published in the EMES Working Papers Series: www.emes.net)

Dees, J. G. (1998) "The Meaning of Social Entrepreneurship", Stanford University, miméo.

Dees, J. G. \& Anderson, B.B. (2006) "Framing a Theory of Social Entrepreneurship: Building on Two Schools of Practice and Thought" in Research on Social Enterpreneurship, ARNOVA Occasional Paper Series, vol.1, no 3, 39-66.

Defourny, J. (2001) "From Third Sector to Social Enterprise", in Borzaga, C. and Defourny, J. (eds) The Emergence of Social Enterprise, London and New York: Routledge, 1-28.

DTI (2002) "Social Enterprise. A Strategy for Success", Department of Trade and Industry, London. Available at: www.dti.gov.uk/socialenterprise/strategy.htm

EMES European Research Network (1999) The Emergence of Social Enterprises In Europe. A Short Overview, Brussels: EMES.

EMES European Research Network (2006) Study on Promoting the Role of Social Enterprises in CEE and the CIS, Initial Overview Study for the UNDP-BRC (Bratislava Regional Centre).

Evers, A. \& Laville, J.-L. (eds) (2004) The Third Sector in Europe, Cheltenham: Edward Elgar.

Fraisse, L., Lhuillier, V. \& Petrella, F. (2007) "Une proposition de typologie des régimes de gouvernance à partir des évolutions observées dans les services d'accueil des jeunes enfants en Europe", Working Papers Series, no 07/01, Liege: EMES European Research Network.

Hulgård, L. \& Bisballe, T. (2004) "Work Integration Social Enterprises in Denmark", Working Papers Series, no. 04/08, Liege: EMES European Research Network.

Lemaitre, A., Laville, J.-L. \& Nyssens, M. (2006) "Public Policies and Social enterprises in Europe: the Challenge of Institutionalization" in Nyssens, M. (ed.) Social Enterprise, London \& New York: Routledge, 259-271.

Nicholls, A. (ed.) (2006) Social Enterpreneurship. New Models of Sustainable Social Change, Oxford: Oxford University Press.

Nyssens, M. (ed.) (2006) Social Enterprise - At the Crossroads of Market, Public Policies and Civil Society, London and New York: Routledge.

Office of the Third Sector (2006) Social Enterprise Action Plan. Scaling New Heights, London.

O'Shaughnessy, M. (2006a) "Irish Social enterprises: Challenges in Mobilising Resources to Meet Multiple Goals" in Nyssens, M. (ed.) Social Enterprise, London \& New York: Routledge, 137-143.

O'Shaughnessy, M. (2006b) An Exploration of the Survival Strategies of Rural Work Integration Social Enterprises, National University of Ireland, Cork (unpublished Ph.D. thesis).

Spear, R. \& Bidet, E. (2003) "The Role of Social Enterprise in European Labour Markets", Working Papers Series, no 03/10, Liege: EMES European Research Network. 


\section{BELGIUM}

\section{The concept of social enterprise}

The concept of social enterprise is still fuzzy in Belgium, but it is more and more frequently used to stress the entrepreneurial approach adopted by an increasing number of organisations in the third sector $^{13}$. The introduction of the "social purpose company" legal framework, in 1996, is clearly linked to this trend. This framework is not, strictly speaking, a new legal form; in fact, all types of business corporations can adopt the "social purpose company" label, provided they "are not dedicated to the enrichment of their members", and their statutes comply with a series of conditions ${ }^{14}$. However, this legal status (revised in 2007) has been adopted by no more than 400 enterprises between 1996 and 2006; this may be accounted for by the fact that it brings with it a considerable number of requirements, in addition to those associated with the traditional company legal form. Most initiatives that meet, to some extent, the criteria of the EMES definition of social enterprise have adopted the legal form of ASBL (non-profit association); this very flexible form allows developing commercial activities, provided that these activities are subordinated to the organisation's social mission. Moreover, the legal form of ASBL is necessary to qualify for several forms of public support. However, some public schemes, such as the "work integration enterprises" scheme in the Walloon region, require that the organisation adopt the legal status of a social purpose company.

\section{The field of work integration social enterprise}

In the current context of persistent unemployment of low-qualified people, the most recognized field of activity of social enterprises is that of "work integration" (Nyssens 2006). This field gathers the organisations whose main aim is to help people who have been excluded from the labour market, reintegrating them through productive activity. Work integration social enterprises (WISEs) are present in a wide spectrum of sectors: environmental sector, building industry, proximity services...

The first work integration social enterprises targeted at disadvantaged people were launched by civil society groups in the 1970 s and $1980 \mathrm{~s}^{15}$; they questioned conventional social policies, which they considered too limited. When these projects began to grow, during the first half of the 1980s, regional governments developed specific public schemes and public financing according to the model of integration developed: "on-the-job training enterprises" (around 70 in Wallonia), which offer transitional traineeship; "work integration enterprises" (around 250 over the country), which create temporary or long-term employment through subsidies decreasing gradually; "social workshops" (around 100 in Flanders), which create long-term employment in a sheltered work environment for jobseekers with serious socio-professional disabilities... (Grégoire 2003). This legal and institutional recognition, in turn, led to a further increase in the number of projects.

Other WISEs, mostly associations, became active though without applying for public accreditation. "Self-accreditation" (i.e. independent classification) and enterprise networking practices also developed alongside legal institutionalisation.

\section{The field of proximity services}

Proximity services are regularly evoked both as new sources of jobs and as a response to new needs that cannot be met by traditional organisations, be they private or public. The federal government, but also the Belgian Communities and Regions, recently took a set of initiatives which demonstrate their interest for this sector.

\footnotetext{
13 This interpretation of social enterprise can be linked to the "market social economy" concept, which is sometimes used in Belgium (see EMES European Research Network, 2007).

14 Among other requirements, SFS statutes must stipulate that "the members seek little or no return on investment". The articles must define a "profit allocation policy in accordance with the enterprise's internal and external purposes". The social purpose company's articles must also provide for procedures allowing each employee to participate in the governance of the enterprise (as a shareholder or/and through a participation in the management of the enterprise).

${ }^{15}$ It has to be noted that WISEs targeted at individuals with disabilities had already been developed in the 1960s.
} 


\section{At the federal level: a service voucher for domiciliary care}

At the federal level, a new public scheme, referred to as the "service voucher system", has been introduced in the field of domiciliary care. This system is open to a broad set of providers - public, forprofit private and not-for-profit providers - and puts them in a situation of competition on a quasimarket. A voucher corresponds to one hour of work; vouchers are bought by the user and then given to the provider organisation, which hires the worker within a normal work contract ${ }^{16}$.

The service-voucher opens a new space for social enterprises. The concerned social enterprises are in some cases entities from the third sector; in other cases, they are rather situated on the - blurred border between the third sector and local public bodies. Social enterprises accredited within the framework of the voucher system can also combine it with other public schemes, such as one of the work integration schemes or the "home-help to families accreditation", a social service scheme. A key question for future research is to determine how this "quasi-market" structure implies itself a possible segmentation, among this diversity of providers, of the customers and/or workers hired.

\section{At the regional level}

The three Belgian Regions have recently adopted public schemes for not-for-profit initiatives (associations, companies with a social purpose or local public bodies organizations) embedded in local networks that combine a work integration objective with a proximity service provision. These schemes are targeted at services which cannot be included in the voucher system. The initiatives have to employ "particularly hard-to-place jobseekers" and provide services which are not provided by traditional private or public enterprises; the services must have a social value-added for the territory (small house fittings and fixtures works, gardening, transport for vulnerable users). They also have to be organized in a participative way, involving the workers (and the users in Flanders) affected by the activity. Accredited enterprises benefit from public funding to cover part of the expenses attached to their twofold social mission, namely providing work integration services and ensuring a better access to proximity services.

The vision of social entrepreneurship underlying these various public schemes in the field of proximity services clearly identifies social enterprise with the "work integration field"; as to the promoters of these initiatives, they can be actors both from the civil society and from the public sector.

\section{Supporting structures}

At least two important facts are to be mentioned as to the overall environment of social entrepreneurship, especially with respect to supporting structures. First, at the national level, a special fund has been set up by the government in 2001 to finance the "social and sustainable economy". Given the financial means allocated to this fund, it has become an important partner for an increasing number of initiatives. Secondly, the "consultancy agencies for the social economy" (in the Walloon region), many of whom are currently working for all kinds of social economy initiatives, are increasingly incited by public bodies to concentrate their efforts on the support to market-oriented initiatives.

\section{References}

EMES European Research Network (upcoming) "The third sector in Europe: An overview of images, concepts and recent trends", Working Papers Series, no. 08/02, Liege: EMES European Research Network.

Grégoire, O. (2003) "National Profiles of Work Integration Social Enterprises: Belgium", Working Papers Series, no. 03/08, Liege: EMES European Research Network.

Nyssens M. (ed.) (2006) Social Enterprise - At the crossroads of market, public policies and civil society, London and New York: Routledge.

Vermer, M.C., Nassaut, S. \& Nyssens, M. (2007) "Le titre-services : un état de la situation", Regards économiques, April 2007, $\mathrm{n}^{\circ} 50$.

\footnotetext{
${ }^{16}$ Any household can buy vouchers at 6.70 euro per unit. The government finances the provider through a subsidy of 14.30 euros per hour and it also offers a tax deduction to the user.
} 


\section{DENMARK}

Anne Liveng

\section{Social enterprise and related concepts}

"Social enterprise" (social virksomhed) as a concept is still new in Denmark; it is just about to enter common vocabulary and Danish discourses on social cohesion (Hulgård \& Bisballe 2004). Until now, it remains primarily used by insiders of the field - mainly researchers in the third sector, social entrepreneurs themselves and third sector representatives in general. Among politicians, the concept has been used as part of an active labour market policy, with an ambition to make traditional enterprises - and especially small and medium enterprises (SMEs) - more socially responsible in matters of integration of unemployed persons into the labour market.

Related concepts used in the Danish context are those of social economy (social фkonomi) and social innovation (social innovation). The concept of social economy is used almost as an equivalent to the concept of social enterprise, but with a lesser focus on democratic ownership or ownership not based on capital than the notion of social enterprise such as defined by EMES (Defourny 2001, quoted by Nyssens 2006).

The concept of social innovation is often linked to a focus on neglected "societal growth"; social innovation is considered as characteristic of enterprises combining both economic and moral values (Ellis 2004, 2006). The concept of social innovation is used - and highlighted as a way to produce new growth - by representatives of the private sector and by researchers in this sector.

\section{Areas of activity of social enterprise and social economy organizations}

Social enterprises and social economy organizations can be classified in four main groups, according to their area of activity:

- Organizations providing voluntary social support, for example crisis centres and refuges for battered wives, "self-help groups" in all areas of social and/or psychological crisis (divorce, suicide, serious illnesses etc.) or thrift shops related to ecclesiastical communities.

- Cooperatives and companies with membership democracy, where members do not necessarily work in the company, but influence decisions and planning through their vote. These organizations can be found in the fields of retail trade, financing, insurance or farming (for example, member-owned insurance companies or cooperative ecological farms producing and selling goods).

- Organizations offering education or on-the-job training to vulnerable groups of unemployed persons. These "work-integration social enterprises" (WISEs) have been studied in the framework of the PERSE project (Hulgård 2006) (see below).

- Local development and urban renewal projects, which set up local partnerships between representatives of the public, the for-profit private and the third sectors (Bisballe 2006).

\section{Social enterprises, at the crossroads of the three sectors}

The integration between the public sector and the third sector is high in Denmark. Danish social enterprises often rely on public support and publicly subsidized staff. The tasks carried out by Danish social enterprises are frequently the same as those carried out by the public welfare state, and the aims and values of social enterprise are often part of a public political strategy. Conversely, social enterprises can take part in raising public debates, and thereby influence the political agenda.

As regards companies characterized by social innovation, they are for example to be found in the area of biotechnology, with companies inventing e.g. products to be used in the third world, fighting malaria or finding landmines. These companies are often small, family-owned or owned by the small group of entrepreneurs/innovators themselves, but ownership structure is usually not central to those focusing on social innovation; as a result, most of these organizations do not meet the criterion stating that the decision-making power should not be based on capital ownership, which in the strict sense excludes them from the field of social enterprises. However, criteria should not be applied too rigidly 
in a national context characterized by the intertwined use of the concepts of social entrepreneurship, social economy and social innovation and by blurred borders between the different types of companies and institutions and their major purposes.

\section{Social enterprise in the field of work integration}

Whereas research into social enterprises in general is scarce, work-integration social enterprises (WISEs) have been studied, as already mentioned, within the framework of the PERSE project.

The landscape of WISEs in Denmark is dominated by local community enterprises offering traineeship and temporary work (lokalt orienterede sociale virksomheder som tilbyder uddannelse og midlertidig beskaftigelse). ${ }^{17}$ Danish WISEs are both similar to and different from European social enterprises as they have been depicted in the EMES ideal-type. On the one hand, Danish WISEs fit the general European picture of social enterprises in that they have a strong entrepreneurial component, while remaining strongly embedded in the associative or co-operative world; indeed, most WISEs were founded by local actors, often in close co-operation with third sector organisations. On the other hand, many Danish WISEs distinguish themselves from most European WISEs as regards the extent of public sector involvement: Danish WISEs (as other organizations in the field of social enterprise), though formally autonomous, are under pressure from public authorities, which often determine their objectives (Riis 2003).

\section{Self-owning institutions in public partnerships}

In Denmark, there is no specific legislation for social enterprises. Among the variety of legal forms adopted by Danish social enterprises, the prevailing one is that of the "self-owning institution" (selvejende institution). The term self-owning institution refers to the legal status of a wide range of cultural, environmental, educational and social institutions and organisations providing various public goods under subcontract, especially within the field of welfare provision - day-care, cheap meals, work integration, rehabilitation, nursing homes, hostels, emergency centres etc. - and within the private school sector. Riis (2003) estimated that there were 9,000 self-owning institutions operating in the social area in Denmark.

The strength of the ties between these organizations, on the one hand, and national, regional and local public bodies, on the other hand, varies from one organization to another - ranging from social enterprises that are more or less integrated parts of the local public welfare system to organizations under little or practically no direct supervision from public authorities.

\section{References}

Bisballe, L. (2006) "Social økonomi og socialt entreprenørskab", in Gamst, B. (ed.) Baredygtig velfard, Copenhagen: Socialpolitisk forlag.

Ellis, T. (2004) The Era of Compassionate Capitalism, Executive MBA-dissertation, Henley Management College, UK.

Ellis, T. (2006) De nye Pionerer - om sociale innovatører, der skaber vakst, vardi og en bedre verden, Copenhagen: Jyllands-Postens Forlag.

Hulgård, L. (2006) "Danish social enterprises: a public-third sector partnership", in Nyssens, M. (ed.) Social Enterprise - At the crossroads of market, public policies and civil society, London and New York: Routledge.

Hulgård, L. \& Bisballe, T. (2004) "Work integration social enterprises in Denmark", Working Papers Series, no. 04/08, Liege: EMES European Research Network.

Nyssens, M. (ed.) (2006) Social Enterprise - At the crossroads of market, public policies and civil society, London and New York: Routledge.

Riis, K. (2003) De selvejende sociale institutioner, hvad skal vi egentlig med dem?, Odense: Center for frivilligt socialt arbejde.

\footnotetext{
${ }^{17}$ The field of WISEs also includes sheltered workshops (beskyttede varksteder), but these initiatives were not included in the sample of WISEs constituted for the purpose of the PERSE project. For a more detailed review of the Danish contribution to this research project, see Hulgård and Bisballe, 2004.
} 


\section{FINLAND}

\section{Pekka Pättiniemi}

In Finland, work integration social enterprises are in practice the only type of social enterprises and, as explained below, the term "social enterprise" (sosiaalinen yritys) is reserved to them by law.

It has to be noted, though, that in a near future the term "social enterprise" might become used in a wider context, as evidenced by some recent developments, e.g. in the field of social and health care. Indeed, most providers in this field would not be referred to as "social enterprises" : many are private enterprises and companies, some are nationwide associations - like the national associations for the disabled, the visually impaired or the deaf - which play a very important role of service provision to their members (these services are often provided by companies owned by these national associations) and only a few are co-operatives or other client or worker-based organisations; but a first discussion on a specific legislation for social enterprises providing social and health care services was held in Parliament in spring 2007, and the subject of enterprises combining social and economic dimensions is awakening growing interest among academics.

\section{Work-integration social enterprise}

The Finnish interest for employing disabled persons in specialised organisations dates back to the years immediately after the Second World War and the 1960s. Since Finland belongs to the group of the Nordic welfare countries, which are characterised by a universal welfare system within which the responsibility to take care of those in need lies on the public sector, in a first stage, from the 1960s to the early 1990s, the questions of work integration and creation of stable jobs for disabled persons were mostly addressed by the public sector. During this period, municipalities and other public sector entities established, with specific state support, over 300 work centres (työkeskus) and sheltered workshops (suojatyökeskus).

Until the 1990s, unemployment rates remained low; as a consequence, there was no real need for social enterprises. But the mass unemployment and deep economic crisis which hit Finland in the beginning of the 1990s changed the situation. In the mid-1990s, social enterprises developed under three forms, besides the abovementioned traditional forms of sheltered workshops and work centres (Pättiniemi 1998):

- village associations (local development and social services);

- $\quad$ associations for the unemployed and labour co-operatives;

- professionals organising the delivery of social and health care services.

In the late 1990s the associations for the disabled and associations for the unemployed conducted several development projects financed by the European Social Fund (ESF) and aiming to develop social enterprises. The good results obtained by some of these ESF projects led to a couple of parliamentary draft proposals for a law on social enterprises. Ministerial committees were also established to assess the need for legislation on social enterprises: they all reached the conclusion that there was no need for such legislation. However, these results did not put an end to the discussion on the need for and role of social enterprises; indeed, the idea of work integration social enterprises as a means of creating employment had generally been accepted by people with disabilities and by those working with the hard core of unemployment. The Ministry of Labour, that struggled with the persistent hard core of structural unemployment (some 270,000 jobseekers, of which 90,000 were disabled workers), also saw social enterprises as an opportunity to solve at least part of the problem. The expected significant change in labour availability in the following years also pointed out to the necessity to raise the employment rate in order to ensure the functioning and financing of the welfare state structures.

\section{Finnish Act on Social Enterprises (1351/2003)}

A Finnish Act on Social Enterprise (1351/2003) was finally adopted at the end of 2003, after a very rapid preparation procedure, and came into force on January 1, 2004. According to this Act, a social enterprise: 
- is an enterprise created for the employment of people with disabilities and of the long-term unemployed $(\S 1)$;

- is a market-oriented enterprise with its own products and/or services;

- should be registered as a trader in the register of social enterprises kept by the Ministry of Labour (\$3);

- should pay all its employees (whether disadvantaged or not) wages set according to the general agreements currently in force in its branch of industry.

Moreover, the bylaws of the enterprise must explicitly mention the aim to employ disabled and longterm unemployed persons; the disabled and the long-term unemployed disabled must represent at least $30 \%$ of the social enterprise's total workforce, and every social enterprise in the register must employ at least one disabled person. No other enterprise than those registered may use the words "social enterprise" in its marketing or in its name.

\section{Public supports for registered social enterprises}

Finnish social enterprises do not benefit from any specific public benefit, and there are thus no restrictions for social enterprises on how to use their profits or surpluses.

Public employment services may grant support to the establishment of a social enterprise and to associations and foundations aiming to promote social enterprises. This supports may not be granted for promoting the commercial development of social enterprises. Due to the restrictions linked to the use of the support, few enterprises have applied for it. Besides this support specifically intended for registered social enterprises, the latter are also eligible to all forms of supports, loans etc. available to any registered enterprise in the country.

When applying for employment supports to cover part of the wage costs of the long-term unemployed and/or disabled members of the staff, registered social enterprises are eligible for an easier procedure than "normal" enterprises, and they can apply for the maximum level of grants, which is not always the case of other enterprises. Concerns about unfair competition, taken up by some organisations representing small and medium-sized enterprises and industries and by some public sector service providers, have made it impossible to introduce other advantages (such as tax deductions) for social enterprises (Pättiniemi 2006).

Finally, also worth underlining regarding the question of public support is the fact that today's Finland is functioning overwhelmingly in a neo-liberal way. For example, municipalities or other public bodies, when outsourcing social services, only very rarely develop procurement practices which could favour social enterprises or associations in the social sector.

\section{Finnish social enterprises in numbers}

Given the limited extent of the benefits linked to the registration as social enterprise, enterprises already active in the area of employment of people with disadvantages and long-term unemployed have shown little interest in registering (Huotari 2005: 109). As of October 16, 2006 only 69 enterprises had been included in the register. Most of these (59) were limited companies or other types of companies, some of them owned by welfare associations or foundations. The other ten enterprises were social economy organisations (co-operatives, associations and a foundation). The evaluation report on the promotion and effectiveness of the Law on Social Enterprises (1351/2003) (Karjalainen et al. 2006) concludes that "the economic importance and effects of social enterprises is minimal; their employment capacity is limited and the supports granted to them constitute no threat to competition. It is worthwhile to consider whether social enterprises' limited effect is only due to the minimal support they receive".

\section{References}

Pättiniemi, P. (1998) "Finland" in Borzaga, C. and Santuari, A. Social enterprises and new employment in Europe, Trento: Autonomous Region of Trentino - South Tyrol.

Pättiniemi, P. (2006) Social Enterprises as Labour Market Measure, Kuopio: Publications E University of Kuopio. 
Huotari, T. (2005) Sosiaalisen yrityksen uudet kehykset, Jyväskylä: University of Jyväskylä (Master's graduate thesis).

Karjalainen, J., Andersen, A., Kuosa, I. \& Pättiniemi, P. (2006) Sosiaalisten yritysten lain toimivuus ja toimeenpano, Employment political research 307, Helsinki: Ministry of Labour. 


\section{FRANCE}

\section{The concept of social enterprise}

In France, the concept of "social enterprise" (entreprise sociale) is still a new concept, whose use and understanding remain limited to a circle of experts and social entrepreneurs; it is not really used as a key concept by policymakers and is not well-known to the wider public. Indeed, the notion of social enterprise is far from having achieved a recognition similar to that gained by the concept of "social and solidarity-based economy", which has gathered coalitions of actors for the last twenty years.

However, some events constitute tangible signs of the progress made by the social enterprise concept within French society. These include, inter alia, the "regional conferences of the social entrepreneurship" in 2003; the creation, during the same year, by some business schools, of a "chair of social entrepreneurship"; some activities launched by the "Agency of valorisation of socioeconomic initiatives" (Agence de valorisation des initiatives socio-économiques, or Avise); and the organisation, in June 2007, of an international conference in Paris on the theme of "Reconfiguring relations between economy and solidarity: associations, cooperatives and social enterprises" ${ }^{18}$.

Moreover, the boundaries between associations and cooperatives are becoming increasingly blurred; this evolution leads to the creation of new legal forms that can be said to focus on the concept of social enterprise. Associations' increasing commercial activities and the role the former play as employers have already led a number of authors (such as Hély 2004) to talk about "associative enterprises" (entreprises associatives). With the changing public regulations and the advent of competition between associations and private companies for the provision of social services (e.g. services to the elderly), market pressure is no longer limited to mutual benefit societies and cooperatives; it has also become a reality for a significant section of the associative sector. In the social sector, in other words, the question of public governance of associations' economic activities blurs the commonly accepted boundaries between market cooperatives and associations.

Obviously, France - as the other EU countries - has seen the development of different kinds of "work integration social enterprise" (Eme and Gardin 2002; Bucolo 2006; Gardin 2006). In the area of the fight against the various forms of exclusion, work integration social enterprises have constituted, in the 1980s and the 1990s, a strategy of fight against unemployment and exclusion which has appeared as innovating insofar as it mobilised work and the creation of enterprises to serve a social goal - namely the integration, into the labour market, of disadvantaged persons (unemployed persons, social aid recipients, low-qualified young workers, handicapped persons etc.). In 2004, the 2,300 registered structures providing work-integration services - work-integration enterprises (entreprises d'insertion), temporary work integration enterprises (entreprises de travail temporaire d'insertion), intermediary associations (associations intermédiaires), integration work sites (chantiers d'insertion) - employed some 220,000 salaried workers (DARES 2005).

\section{A new legal status, the "collective interest cooperative society"}

The main statutory innovation in recent years in France has been the creation, in 2002, of a new legal form: that of "collective interest cooperative society" (société coopérative d'intérêt collectif, or SCIC). The SCIC is a private, collective-interest organisation; this new form of co-operative undertaking brings together employees, users, voluntary workers, local and regional authorities and any other partner wishing to work together on a given local development project. The creation of the SCIC legal form is one of the outcomes of a debate on the need to take into account, in the range of legal forms available to social economy enterprises, the different stakeholders involved in the setting up of local initiatives. It also results from the work of think tanks organized by the French co-operative movement regarding research being carried out and initiatives being set up in Europe in the area of social enterprise (Borzaga and Defourny 2001); the experience of social co-operatives in Italy, in particular,

\footnotetext{
${ }^{18}$ Conference organized by Jean-Louis Laville and the CNAM with the support of EMES.
} 
was a source of inspiration. However, after five years of existence of this legal form, only 94 SCICs have been created ${ }^{19}$.

\section{Social entrepreneurship support and funding}

One of the recurrent issues regarding social entrepreneurship is the lack of recognition of their specificity in the public programmes and funds for starting a business or running a small enterprise. One of the goals of the new local public action in favour of the social and solidarity-based economy (Laville et al. 2005) is to launch special methodological and financial support mechanisms taking into account the immaterial investment, the collective dimension, the non-monetary resources and the positive externalities of social entrepreneurship.

Besides, public representatives in charge of the social and solidarity-based economy increasingly try to include work integration-related social clauses in public markets.

There exist, in most places, local schemes aiming to support integration through economic activity; but a major stake of public policies for the social and solidarity-based economy is to manage not to make the support to social entrepreneurship conditional upon the sole goals of job creation and integration of disadvantaged people into the labour market. As a matter of fact, for many social entrepreneurs, what motivates them to create an enterprise is not the fight against exclusion, but sustainable development, international solidarity, the creation of social links, artistic and cultural activities etc. Job creation and work integration, in such cases, are only indirect consequences of the activities set up rather than their main goal.

\section{References}

DARES (2006) Première Information et Synthèse, L'insertion par l'activité économique en 2004, avril, ${ }^{\circ} 15.1$ (http://www.travail.gouv.fr/IMG/pdf/2006.04-15.1.pdf).

Borzaga, C. \& Defourny, J. (2001) The Emergence of Social Enterprise, London and New York: Routledge.

Bucolo, E. (2006) "French social enterprises: a common ethical framework to balance various objectives", in Nyssens, M. (ed.) Social Enterprise - At the crossroads of market, public policies and civil society, London and New York: Routledge.

Eme, B. \& Gardin, L. (2002) "Les entreprises d'insertion par le travail en France", Working Papers Series, no 02/01. Liege: EMES European Research Network.

Gardin, L. (2006) "A variety of resources mixes inside social enterprises", in Nyssens, M. (ed.) Social Enterprise - At the crossroads of market, public policies and civil society, London and New York: Routledge.

Hély, M. (2004) "Les différentes formes d'entreprises associatives", Sociologies pratiques, nº, pp. 27-55.

Laville, J.-L., Magnen, J.-P., França Filho, G.-C. \& Medeiros, A. (2005) Action Publique et Economie Solidaire, Toulouse: Editions Eres.

\footnotetext{
${ }^{19}$ http://www.scic.coop/, May 2007.
} 


\section{GERMANY}

Karl Birkhölzer

\section{The paradoxical situation of social enterprises in Germany}

Social enterprises and social entrepreneurship in Germany are facing a paradoxical situation: on the one hand, they almost do not exist on the political agenda nor in the public debate or the media, and not even in the academic discourse, where their study is limited to a small circle of individual experts with almost no support from official institutions. On the other hand, a social enterprise culture of quite considerable size and importance does exist; some of its elements are based on traditions which date back to the 19th century.

The reasons behind this situation are basically twofold.

First, the concepts of social enterprise and social economy (as a whole distinct third sector) are still ignored or rejected by the majority of politicians and economists alike in Germany. The factors accounting for this situation are rather complex:

- The terms were imported from abroad by transnational research projects and in the first place did not mean anything to a German audience.

- Furthermore, it was expected that social conflicts in post-war Germany would be solved by a special type of social partnership agreement which was referred to as the "social market economy", and from this point of view, there was no need for new approaches such as the social economy and/or social enterprises. The situation became even more complex as the consensus between the social partners involved in the social market economy eroded heavily under the hegemony of neo-liberal economic thinking, and (more or less at the same time) the so-called "socialist economy" broke down in East Germany.

In this context the terms "social economy" and "social enterprise" were confronted with a lot of prejudices and misunderstandings.

Secondly, those organizations which could be qualified as social enterprises do not really see themselves as belonging to a wider social economy sector. They are still separated and split up in a variety of different "milieus", each with its own terms, identities and organisations; quite often, they do not even communicate with each other. Although social enterprises play an important role in the field of fighting unemployment, poverty and social exclusion, there are no real support schemes at the regional or national level. The only exception is that of so-called "integration enterprises", which can ask for special subsidies for employing disabled people, but these schemes are open to all types of enterprises.

Things have started to change only recently, and very slowly. In November 2006, for example, a first national congress on the "solidarity-based economy" took place in Berlin.

\section{Social enterprises' types, quantitative importance and fields of activity}

In spite of such a difficult overall context, attempts to better identify the third sector in Germany have been made, among which a national survey conducted a few years ago (Birkhölzer et al.., 2004). Further steps toward a better knowledge of social enterprises could use that work as a background since the following operational criteria were chosen to define the boundaries of the social economy:

- organisations to be included in the study should give priority to social and/or communityoriented objectives;

- their entrepreneurial activities should be initiated by civil society actors;

- they should have a not-for-private-profit orientation;

- their organisational structure should be of the cooperative type.

A high number of social enterprises could be identified in such a third sector which, in Germany, comprises an older part, consisting of cooperatives, welfare organisations, foundations and traditional associations, and a rather new part, consisting of integration enterprises, volunteer service agencies, 
self-help initiatives, socio-cultural initiatives, self-managed enterprises from the "alternative" movement, women's and eco-movements, work integration companies, local exchange and trading systems, and neighbourhood and community enterprises.

Although not labelled as such, many social enterprises are working with economically and socially excluded persons, in the fields of social services, environment, sports and culture, but there are activities in all sectors, including agriculture and high-tech production. Of course, there are a lot of welfare schemes for the integration of unemployed or otherwise socially excluded people, but these are not appropriate for the creation of sustainable social enterprises. As it was already pointed out, there are no specific public schemes supporting social enterprises and only a few partnership agreements at the local and regional level which deal with the provision of public goods and services (one example is the Berlin Development Agency for Social Enterprises and Neighbourhood Economy - see references).

\section{Current challenges}

The main problem remains the lack of acceptance and recognition of the concept of social enterprise, but other challenges also appear as important. The lack of an appropriate framework, including specific legal structures and financial as well as organisational support structures, is also detrimental to the sector. Finally, social enterprises themselves need to work on the development of specific microeconomic strategies. Possible improvements of the situation could be expected in the follow-up of a national programme called "Social City", which is dedicated to the development of the most deprived areas in German cities, as social enterprises could play a key role within that process.

\section{References}

Birkhölzer, K., Kistler, E. \& Mutz, G. (2004) Der Dritte Sektor. Partner für Wirtschaft und Arbeitsmarkt, Wiesbaden.

Birkhölzer, K., Klein, A., Priller, E. \& Zimmer, A. (eds.) (2005) Dritter Sektor/ Drittes System. Theorie, Funktionswandel und zivilgesellschaftliche Perspektiven, Wiesbaden

Technologie-Netzwerk Berlin e.V. (2005) Berlin Development Agency for Social Enterprises and Neighbourhood Economy, Berlin (www.soziale-oekonomie.de) 


\section{IRELAND}

Mary O'Shaughnessy

\section{Types of Irish social enterprises}

Social enterprises are part of the Irish social economy, which also includes charities and co-operatives. In the early 1990s, Planet (the network of area-based partnership companies) and the national social economy group developed a typology of social economy organisations on which subsequent statutory funding measures came to be based on this typology included three main subsets:

- community businesses, which are generally financed from trading income alone.

- deficient-demand social enterprises, which tend to emerge where the demand for particular goods and services within a community is not matched by resources to pay for the provision of the demand, due to such things as local disadvantage or low-density population;

- enterprises based on public sector contracts, which deal with the potential for subcontracting public sector expenditure in disadvantaged areas to local community businesses and enterprises.

A key attempt to categorise Irish social enterprises has been undertaken by O'Hara (2001), who has developed five broad categories of Irish social enterprises on the basis of their objectives, activities and operation. These categories are as follows:

- work integration social enterprises, associated with the integration of members of excluded groups into the labour force;

- credit unions;

- $\quad$ social enterprises providing personal and proximity services;

- local development organisations;

- housing co-operatives.

The Irish credit union movement, which was established in 1957, is an excellent example of a successful social enterprise. A credit union consists of a group of people who collectively save their money and lend to each other at a reasonable rate of interest. The Irish credit union movement is a voluntary movement, and each credit union is an independent autonomous body with support and advisory services organized by a central body, the Irish League of Credit Unions (ILCU). The ILCU is an umbrella organisation for most credit unions in Ireland. There are 547 credit unions in the country, serving over 3.2 million members, with an estimated 3.6b euros turnover. And with an estimated 3,800 employees and a $24 \%$ share of the national personal loan market the credit union has been established as a viable alternative financial institution in Ireland (Carroll \& Beckett 2007).

Housing cooperatives, for their part, constitute a distinct form of not-for-profit mutual housing association; they are working to relieve housing needs for community benefit. The members of the cooperative are the users of the housing services provided by the cooperative. Housing cooperatives originated in the $19^{\text {th }}$ century as mutual aid societies seeking to clear slums, facilitate security of tenure and provide affordable housing options. Small home-ownership building cooperatives, which developed in Ireland during the early 1950s, were more community-based and less philanthropic-led than their forerunners; this new wave of initiatives were established by local self-help groups seeking to provide housing for themselves. The National Association of Building Cooperatives (NABCO) is the key source of information and advice about the formation and management of housing cooperatives. The association, which acts as an umbrella body for all housing co-operatives, was formed by representatives of cooperative housing societies in 1973; it is registered as a non profit Industrial and Provident Society under the current Irish legislation. There are 10 housing co-operatives with an estimated 2,009 members and a $3.5 \mathrm{~m}$ euros turnover; they employ approximately 22 employees (Carroll \& Beckett 2007). 


\section{Legal structures}

Irish social enterprises adopt a variety of legal structures, including the company structure limited by guarantee or share, industrial and provident societies, and co-operatives. Social enterprises can also apply for charitable status, which provides them with certain exemptions from certain taxes. The Revenue Commissioners determine whether a body is entitled to charitable tax exemption under the Taxes Consolidation Act 1997. Charities legislation is currently under review with a view to reform as the charities sector in Ireland is unregulated. As a consequence there is no such thing as a registered charity in Ireland at present and no statutory definition of what a "charity" is.

\section{Statutory support}

Two main types of social enterprises receive statutory support: local development social enterprises and work integration social enterprises. The former have typically emerged with the support of statutory funding made to support area-based development partnership structures, such as the EU LEADER initiative and national operational programmes for local Urban and Rural Development. As to work integration social enterprises (WISEs), there is a strong relationship between Irish WISEs and national active labour market policies (ALMPs). ALMPs were introduced in the 1970s in response to rising national unemployment levels. Community Employment, Job Initiative and the national Social Economy Programme are the most typical ALMPs in this regard. They essentially entail the provision of subsidies to employers and training schemes targeted at the long-term unemployed. There are three main types of Irish WISEs: sheltered employment, local development and social economy WISEs.

\section{References}

Carroll, B \& Beckett, M. (2007) "The Current Scope of Co-operatives in the Irish Economy", Centre for Co-operatives Studies, UCC, paper presented at the inaugural seminar of the Forum for the Cooperative Movement in Ireland, UCC.

O’Hara, P. (2001) "Ireland: Social Enterprises and Local Development", in Borzaga, C. \& Defourny, J. (eds) The Emergence of Social Enterprise, London and New York: Routledge.

O’Shaughnessy, M. \& Briscoe, R. (2005) "Serving Ourselves", in Briscoe, R. \& Ward, M. (eds) Helping Ourselves, Success Stories in Co-operative Business and Social Enterprise, Dublin: Oak Tress Press.

O’Shaughnessy, M. \& O'Hara, P. (2004) "Work Integration Social Enterprises in Ireland", Working Paper Series, no. 04/03, Liege: EMES European Research Network.

O'Shaughnessy, M. \& Moroney, A. (2001) Project Development for Social Enterprises, Centre for Co-operative Studies, Cork: University College Cork. 


\section{ITALY}

\section{Carlo Borzaga, Giulia Galera and Flaviano Zandonai}

\section{From social cooperatives to a broader legal conception of social enterprise}

Social cooperatives have so far represented the main type of social enterprise in Italy. Since the approval of Law 381/1991, which introduced the social cooperative legal form, these organisations have registered an average annual growth rate ranging from 10 to $20 \%$. In 2005, there were over 7,300 social cooperatives; they employed 244,000 workers.

However, this impressive development of social cooperatives has not prevented other types of third sector organisation from developing social entrepreneurial activities, and a law on social enterprise (Law 118/2005) has recently been adopted, which undoubtedly constitutes a landmark in the history of the Italian third sector.

The new law incorporates the principle of pluralism of organizational forms and does not consider the organizational structure as a condition for eligibility as a social enterprise. The law divides eligible organizations into two sub-sectors: that of companies and that of organizations that are not companies. The innovative character of the law results from both the opening towards new sectors of activity, other than welfare, and the variety of the types of organizations eligible to become social enterprises.

As said, the law crosses the boundaries of legal and organizational forms, enabling various types of organization (not only cooperatives and traditional non-profit organizations, but also investor-owned organizations, for instance) to obtain the "legal brand" of social enterprise, provided they comply with the non-distribution constraint and organize the representation of certain categories of stakeholders, including workers and beneficiaries.

The law also provides that associations and foundations that want to be registered as social enterprises must provide evidence of their entrepreneurial nature; conversely, investor-owned companies applying for the social enterprise brand have to comply with certain requirements regarding the distribution of benefits (namely respecting a total non-distribution constraint) and participation of relevant stakeholders.

Interestingly, the definition of social enterprise introduced by the Italian legislator mirrors the EMES definition, except on three points:

- . the law imposes a "total non-distribution constraint" on social enterprises. Indeed, the latter have to invest all their income in their core business or in increasing their assets;

- the goals pursued and the sectors of activity overlap;

- the criteria of stakeholders' involvement (workers and users) prescribed is weaker than the one proposed by EMES, as the definition of "involvement" introduced is indeed very wide.

\section{Business activity of social utility}

The law on social enterprise identifies a number of new fields of business activity, defined as fields of "social utility". According to Paragraph 1 of Article 2, sectors of public utility are precisely: a) welfare; b) health; c) welfare-health; d) education, instruction and professional training; e) environmental and eco-system protection; f) development and cultural heritage; g) social tourism; h) academic and post-academic education; i) research activities and delivery of cultural services; 1) extracurricula training; and $\mathrm{m}$ ) support to social enterprises.

Furthermore, the law acknowledges the experience gained by social cooperatives in the field of work integration. Enterprises active in this latter field can apply for the social enterprise label, whatever their field of activity. What matters is that the activity be carried out by employees of whom at least $30 \%$ are disadvantaged or disabled. In addition to the categories provided for by law 381/91, longterm unemployed people are also taken into consideration. However, no fiscal benefits or social security reductions are granted. 


\section{Socio-economic context: current challenges}

The abovementioned factors of institutional innovation create a favourable context for the development of social enterprises; but other variables, related to the socio-economic context, also have to be taken into account in analysing the state of the art and the prospects of development of social enterprises, given the potential impact of these variables on the start-up of new enterprises. Variables to be considered include:

- the shrinkage of public resources in the concerned fields of activity, including social policies. Hence, two controversial phenomena are currently at work: re-publicization, on the one hand (i.e. services previously contracted out by public authorities to third sector providers with public subsidies are now being again provided directly by public organisations), and the entry of new, for-profit providers (above all single individuals), in fields of activity traditionally occupied by social enterprises, on the other hand;

- the substantial legitimization of social enterprises in the framework of local governance systems, where new policies are planned in sectors of relevance for social enterprises;

- the possibility for social enterprises to implement new partnerships, involving other third sector actors, especially banking foundations - not only for representation and lobbying purposes, but also with a view to bringing about innovative welfare models at the community level;

- the establishment of fruitful relations with other economic actors - beyond a few "best practices" examples in the sphere of corporate social responsibility - with a view to integrating disadvantaged workers into work.

Some of these variables (such as the first one) can hinder the creation and development of social enterprises, while others can positively impact the sector's perspectives and prospects (this is the case of the last three variables mentioned).

Social cooperatives have developed intensively in a specific niche; the next challenge Italian social enterprises will have to face is the expansion of their activities in a wider set of economic sectors, and under a plurality of organizational forms.

\section{References}

Borzaga, C. \& Defourny, J. (2001) The Emergence of Social Enterprise, London and New York: Routledge.

AAVV (2005) "La Legge Delega sull'Impresa Sociale: Riflessioni nella Prospettiva dei Decreti Delegati", Impresa Sociale, n. 2 ,15, Vol. 74, June.

AAVV (2005) "Dopo il Decreto Delegato sull'Impresa Sociale: criticità, Prospettive, Politiche", Impresa Sociale, n. 3, 16, Vol 75, July-September. 


\section{POLAND}

\section{Recognition of the social enterprise concept}

The concept of social enterprise is an emerging notion in Poland; there is not yet a common definition of the concept, which originates in the concepts of third sector, non-profit sector and cooperatives. The specificity of social enterprises, compared to third sector, non-profit or cooperative organisations in general, lies in the fact that they are profit-makers, although not profit-maximizers, and that they focus more on general interest/community interests, and not only on mutual interest goals.

Social enterprises are still rarely a subject of public discourse and they are only partially integrated into policies and laws. Only recently have a few policy debates recognized the potential of third sector and social enterprises as a vehicle for creating services for households and communities and jobs for hard-to-employ groups.

\section{Fields of activity}

Despite these obstacles, recent development dynamics indicate that social enterprises are growing in the field of work integration, some social services and community services. Indeed, social enterprise have come into being as a response to the human costs of transition - mainly the mass increase of unemployment and poverty and the welfare gap created by the shrinking of the public welfare system. All categories of work integration social enterprises - those providing transitional occupation, those aiming at the creation of permanent self-financed jobs and those based on socialization through productive activities - have registered significant growth lately. This trend was reinforced by the European Union's policy recommendations and structural funds to address problems of social exclusion and unemployment (e.g. European Employment Strategy, Lisbon Strategy, White Paper on European Governance) as well as donors' programmes, in cooperation with some local government bodies, relevant ministerial authorities, academics, experts and civil society groups.

\section{Legal forms}

Most social enterprises in Poland operate within the legal framework of associations or other voluntary organizations, foundations or cooperatives. Beside these traditional legal forms, there are several entities that do not have a legal personality and act as substructures of associations, foundations and other voluntary organizations, e.g. vocational enterprises for the handicapped (Zakłady Aktywności Zawodowej, or ZAZ), social integration centres (centra integracji społecznej, or CIS), social integration clubs (Kluby Integracji Spotecznej, or KIS), job-seeking clubs (Kluby Pracy, or KP) and workshops of vocational therapy (Warsztaty Terapii Zajęciowej, or WTZ).

Poland has also introduced recently a new legal form, specifically intended for work integration social enterprises: the Act on Social Cooperatives, which was passed in April 2006, allows selected needy groups (such as ex-convicts, long-term unemployed, disabled persons and former alcohol or drug addicts) to set up a social cooperative. This act constitutes an important policy innovation in the field of employment for disadvantaged groups. Social cooperatives are entitled to perform public tasks, similarly to associations and foundations, and to produce goods and services on a not-profitmaximizing basis.

The "legal future" of social enterprises in Poland is still uncertain. Indeed, some analysts are in favour of expanding the range of legal forms available to social enterprises, namely by allowing these to adopt the legal form of limited liability company and stock company of public purpose (Barański 2006). In parallel, the possibility to legally forbid associations and public benefit organizations to carry out any economic activity has recently been debated. Other analysts are critical of the few existing non-profit commercial companies, which they accuse of deconstructing the boundaries of the third sector. There is also a recent initiative of some social economy activists to introduce a new legal form of social enterprise, but this initiative has not yet received significant support, be it from politicians or from the social economy sector itself. 


\section{Public schemes and procurement practices}

There are a few public schemes at the national level supporting the mission of third sector and social enterprise organizations. The Public Fund for Citizen Initiatives (Fundusz Inicjatyw Obywatelskich, FIO), created for the years 2005-2007, awarded grants ranging from about 1,000 euros to about 50,000 euros, to over 1,300 associations and foundations. There are also specific public schemes supporting the creation and mission of social cooperatives - namely the "seed money for start-ups" distributed by the "Regional Funds for the Social Economy" (Regionalny Fundusz Ekonomii Spotecznej). The latter, which have been in existence since 2004, have been replaced in 2006 by "Support Centres for Social Cooperatives" (Ośrodki Wsparcia Spótdzielczości Socjalnej, OWSS) supporting social cooperatives' ongoing activities. There are 11 Support Centres in Poland; each of them has been granted a sum of approximately 40,000 euros to award grants and render support services to social cooperatives.

Local public authorities, according to the Act on Public Benefit and Volunteering of 2003, may delegate public tasks to social enterprises (including social cooperatives), on the basis of a competitive bidding procedure or - more often - of the so-called "open competition of offers". The most frequently delegated public tasks include sport and recreational activities, social services and services for the handicapped, health promotion, local development (agritourism and ecology), educational services, cultural and arts activities and national heritage protection.

\section{Training structures}

Several Polish universities offer training programmes developed for social enterprise leaders and staff. One example is a pilot training/educational programme for social enterprise managers, which was launched in March 2006 at Warsaw University's Institute of Social Policy, within the framework of the EQUAL project "We Have Jobs". This innovative postgraduate programme for existing and would-be managers in social enterprises and local leaders is supplemented by winter and summer schools on social enterprises with a series of national and international visits. Various state and private universities also include the subjects of social economy and cooperative movement to the curricula of the general studies (mainly within the faculties/institutes of economics, management, law, social policy, economics and management of agriculture etc.); some of them also organize postgraduate studies on these topics.

Some cooperatives and other social economy organizations themselves organize training courses for the managers/employees/elected leaders of social enterprises. Most of them focus on very concrete issues (accounting, taxes, marketing, quality control, personnel management etc.). Most of these courses are financed by the participants themselves (sometimes with the support of the organizations of which they are members/employees); sometimes they are organized in the framework of EU or national projects.

\section{References}

Barański, J. (2006) Limited Liability Company and Stock Company of Public Purpose, manuscript, Warsaw.

Chludziński, M. \& Gluziński, A. (2007) "Funding sources of social enterprises in Poland" in Leś, E. \& Ołdak, M. (eds) Social Enterprise in Local Development, Warsaw: Warsaw University and Collegium Civitas.

Izdebski, H. (2003) Law on Public Benefit Activity and Volunteering. Commentary, Warsaw.

Leś, E. \& Jeliazkova, M. (2005) "The Social Economy in Central East and South East Europe", in The Social Economy in Central East and South East Europe: Emerging Trends of Social Innovation and Local Development, Background Report, Trento: OECD, September 22-23.

Strzała, A. \& Jaworski, J. (2007) The Report on functioning of the law on public benefit organizations and volunteering in 2005, Department of Public Benefit, Ministry of Labour and Social Policy, Warsaw. 


\section{PORTUGAL}

\section{Heloísa Perista}

\section{The field of social enterprise in Portugal}

The concept of social enterprise, as such, is still relatively absent both from mainstream policy and scientific debate in Portugal. However, there is an on-going debate about the larger set of third sector organisations, to which social enterprises belong. In the last few years, this debate has revolved almost exclusively around the concept of "social economy" and, more specifically, around the "Social Employment Market" (Mercado Social de Emprego), which aims at the work integration of disadvantaged persons.

Most third sector organisations have been traditionally oriented to the supply of social services, namely to children, elderly people and people with disabilities. Indeed, the Portuguese system of social security ${ }^{20}$ is based on a model in which responsibilities are shared between the state - through public bodies, including local authorities - and the non-governmental and non-profit sector. According to the principle of complementarity, it recognises the articulation among the various forms of social protection - public, social, cooperative, mutual and private for-profit organisations - for developing, replacing or complementing state initiatives for social security purposes and especially for social action $^{21}$.

But third sector organisations have recently been growing and diversifying, penetrating new areas and developing new forms of response, including in the field of work-integration. An important factor accounting for this evolution is the launch, in 1998, within the framework of the Social Employment Market, of a specific public scheme - the so-called "Integration Companies" (Empresas de Inserção) scheme. "Integration Companies" receive public technical and financial support. They may be promoted by different types of third sector organisations: misericórdias (charitable organisations closely related to the Catholic Church), mutual benefit associations, private institutions of social solidarity (Instituições Particulares de Solidariedade Social, or IPSS) and cooperatives, mainly from the social solidarity branch. They are practically the only form of organisation in Portugal combining social and economic purposes; talking about social enterprises in this country thus virtually amounts to talking about Integration Companies. Consequently, the present contribution will focus on the latter.

\section{Main recent developments and debates on WISEs}

Previous research on social enterprises, developed within the EMES European Research Network, analysed Integration Companies in detail (Perista and Nogueira 2002, 2004, 2006). Information recently released by the Social Employment Market Commission (Rebelo and Ventura, 2006) also allow for a retrospective analysis of some data regarding the evolution of Integration Companies, from the launch of this measure, in 1998, until 2005.

Between 1998 and 1999, the number of Integration Companies increased by more than four times, rising from 67 to 284 . This number continued to increase until 2001, when it reached a pick of 611 . In 2005, 521 Integration Companies were in operation in Portugal.

The evolution in the number of beneficiaries paralleled the rise in the number of organisations; the former increased steadily between 1998 and 2002 (from 555 to 4,693 beneficiaries); in 2005, integration companies served 4,265 people. In June 2006, however, the number of beneficiaries had decreased to $3,268^{22}$. Women represent $75 \%$ of all the beneficiaries of Integration Companies; this may be - at least partly - related to the main sectors of activity, which are traditionally highly feminized ones (most integration companies are active in the fields of homecare support, gardening, laundry and restoration). As to age distribution ${ }^{23}$, beneficiaries between 25 and 44 years old constitute the largest group (30.5\% of beneficiaries). However, a significant $11.5 \%$ are over 49 , which seems to

\footnotetext{
${ }^{20}$ Cf. Lei de Bases da Segurança Social, Law no 32/2002, of 20 December.

${ }^{21}$ The activity of "private institutions of social solidarity", for example, is regulated, fiscally controlled and financially supported by the state, through co-operation agreements.

${ }^{22}$ There is no information available on the number of integration companies in June 2006.

${ }^{23}$ Source: IEFP, Departamento de Planeamento Estratégico, in Rebelo and Ventura, 2006.
} 
indicate that Integration Companies are also covering older workers, who experience specific difficulties in terms of integration into the labour market. The population covered by Integration Companies shows a low level of education: $42.3 \%$ have at most 4 years of schooling, another $32.3 \%$ have 6 years of schooling, and $6.7 \%$ of the beneficiaries do not even have any schooling degree ${ }^{24}$.

Still regarding the retrospective analysis of data referring to Integration Companies, it is interesting to consider the number of people covered by the so-called "Integration Award" (Prémio de Integração), launched in 2003 and addressed to the employers who sign a permanent work contract with people in integration process. Until now, the proportion of beneficiaries concerned by this Integration Award has always remained under the threshold of $5 \%$ of the total number of beneficiaries (115 workers in 2003, 219 in 2004, 184 in 2005 and 34 in the first half of $2006^{25}$ ). This may be regarded as a sign of the frailties of Integration Companies; indeed, concerns have been expressed (for instance in Perista and Nogueira 2006) about the sustainability of Integration Companies, especially after the end of the subsidy period.

A recent study (Santos 2006) addressed this issue on the basis of case studies of some Integration Companies run by misericórdias. The main reason why the "Union of the Portuguese Misericórdias" (União das Misericórdias Portuguesas) decided to commission this study has to do with the fact that the period (seven years) of funding of the first Integration Companies was coming to an end; an evaluation of the outcomes and drawbacks of this measure was thus needed. Although the report concluded that Integration Companies would be able to survive after the end of the subsidised stage, several reforms were pointed out as necessary, among which:

- a better definition of the fiscal and legal framework of Integration Companies;

- the opening of the possibility to create Integration Companies with a minimum of three workers (the minimum of five workers currently imposed by law being considered as excessive);

- a longer training period for the workers in integration process.

The report also pointed out that some of these disadvantaged workers did not in fact have real possibilities of a normal integration in the labour market, and underlined the fact that most part of the services provided by Integration Companies, namely proximity services, required regular state support (demand-side support) in order to be financially sustainable, in particular because (potential) clients only have weak possibilities to pay a price covering the real costs of the services.

\section{References}

Perista, H. \& Nogueira, S. (2002) "National Profiles of Work Integration Social Enterprises in Portugal", Working Papers Series, 02/09, Liege: EMES European Research Network,

Perista, H. \& Nogueira, S. (2004) "Work Integration Social Enterprises in Portugal", Working Paper Series, 04/06, Liege: EMES European Research Network.

Perista, H. \& Nogueira, S. (2006) "Work Integration Social Enterprises in Portugal. A Tool for Work Integration?", in Nyssens, M. (ed) Social Enterprise - At the crossroads of market, public policies and civil society, London and New York: Routledge.

Rebelo, M. J. \& Ventura, S. (2006) Mercado Social de Emprego: 10 Anos a Promover a Inclusão. MTSS / Comissão do Mercado Social de Emprego.

Santos, J. C. (2006) Empresas de Inserção - Valor, Competitividade e Impacto nos Beneficiários, União das Misericórdias Portuguesas.

\footnotetext{
${ }^{24}$ Source: IEFP, Departamento de Planeamento Estratégico, in Rebelo and Ventura, 2006.

${ }^{25}$ Source: IEFP, Balancete Mensal Final 2005, in Rebelo and Ventura, 2006.
} 


\section{SWEDEN}

Yohanan Stryjan and Victor Pestoff

\section{Social services and labour market integration}

The public sector's increasing inability to satisfy demand and quality expectations stimulated the emergence of the first social enterprises in social services in the 1980s. Cooperative childcare was the first and most successful field, presently providing over ten percent of child-care services (Pestoff 1998). In other welfare services the trend peaked in 1992, only producing limited results (Stryjan 1996).

Labour market integration in Sweden is steered by a separate set of institutions. The progressive erosion of these and the restructuring of mental health-care in the late 1980s fuelled an increase in openly marginalized groups (Stryjan and Wijkström 1996; Stryjan 2001). The first work-integration social enterprises (WISEs) were started as a response by those directly affected and/or by committed public employees; this grass-roots' action produced new organizational models. No specific institutional/legal groundwork was laid beforehand, and formal financing agreements or rehabilitation contracts were negotiated locally with some municipalities. Likewise, relations with labour-market and social-insurance organs were developed locally, but never regulated nationally. On the whole, the level of institutionalization remains extremely low, which increases the enterprises' vulnerability but also provides for a high level of innovation.

WISEs gained increasing recognition, first at the directly involved county and municipal levels (which dispense medical care, social aid and residential care), and gradually at the national level as well. A recent national review of mental health and rehabilitation systems ${ }^{26}$ acknowledges social enterprises' important contribution to rehabilitation but also notes the makeshift character of their financing, and the lack of adjusted tendering mechanisms as major development hinders, and recommends a review of WISEs' situation. It is unclear whether this recommendation will be followed by the present government.

Business-wise, WISEs are active in a broad variety of branches, ranging from technical ones (as logistics and a scrap yard) to services, gardening and janitoring (Stryjan 2006). Some enterprises provide services to the population, while others rely on business-to-business contracting. Only a handful have municipal contracts in their mainstream business activity, though contracts for rehabilitation placements and occupation are a source of additional revenue for some. No incentive for a commercial binding to public authorities exists, since the Swedish interpretation of EU public procurement legislation does not allow for preferred treatment for social enterprises, and periodic public tendering makes public agencies less reliable as business partners than the private ones.

\section{Organizational forms}

Cooperatives are the dominant organizational form of social enterprise, in keeping with the Swedish organizational tradition and with a pervading ethos that emphasizes self-help, autonomy and democracy. Typically, the term "social cooperative" became synonymous with "WISE" in Swedish usage $^{27}$. In fact, WISEs follow two main organizational models: social cooperatives proper, that are worker cooperatives run by the participants themselves, and community enterprises, which have a broader agenda and are characterized by a multi-stakeholder governance.

In the day-care and school sector, three organizational models co-exist: parent cooperatives, worker cooperatives, and voluntary (commonly multi-stakeholder) associations promoting special pedagogical approaches (Pestoff 1998).

Sweden lacks specific incorporation forms for social enterprises, which thus adopt standard cooperative incorporation forms: economic association (ek. för.), and - more rarely - voluntary association (ideel för.), sometimes combined in a double-tier structure. A new legal form, namely that

\footnotetext{
${ }^{26}$ SOU 2006: 100, nationally known as The Milton report.

27 The Milton report (see above) applies the label "social cooperatives" to all WISEs, though a handful of important actors (most notably the Fountain-house foundation) adopted different models.
} 
of "Firm with Limited Profit Distribution" (Aktiebolag med särskild vinstutdelningsbegränsning) introduced in 2006 by the Social Democratic Government (prop 2004/05: 178) to stave off pressures for privatization of public education and health care, failed to win any noticeable following thus far, and its relevance for social enterprises is doubtful.

\section{Recent developments}

The September 2006 elections explicitly focused on labour-market issues and yielded a firm parliamentary majority for the Alliance for Sweden right-centre coalition. Though committed to a reform of active labour market policy (ALMP) and friendly to local governments' ambitions to privatize social services, the present government, unlike its liberal predecessor from 1991-1994, avoids sweeping proclamations, making future projections extremely difficult.

Inasmuch social cooperatives developed in the fault lines of the ALMP, and largely subsist on the market imperfections of this system, any sweeping reform may have profound consequences for the entire organizational population. Social cooperatives' superior ability to perform tasks that ALMP organs had the mandate and resources but lacked the competence to tackle often gained them a position of subcontractors. Unfortunately, subcontractors, regardless of their competence, are often shed off in major reorganizations. Streamlining the labour-market system may lead to social cooperatives being deprived of vital revenue sources, unless specific provisions for their survival are made.

In a similar manner, privatization drives by key municipalities and the introduction of tax breaks on proximity services may provide both opportunities and threats. The opening for privatization bids on service provision opens new fields of operation for initiatives by committed personnel and participants' groups. However, both the complexity of tender procedures and the uncertainties and risks that this process entails presuppose a deal of resources and economic reserves that precisely these groups lack. Furthermore, the tender regime implied by the Swedish Law on Public Procurements (Lagen om offentlig upphandling, or LOU) prevents authorities from considering social factors. Within elderly care, that was opened for privatization in a similar manner in the 1990s, this configuration eventually led to the field being taken over by corporate actors (Stryjan 1996). Though the present reform course may lead to promising developments, some basic institutional adjustments need to be made if this promise is to be met.

\section{References}

Pestoff, V. (1998) Beyond the Market and State, Ashgate: Aldershot.

SOU (2006) Ambition och ansvar. Nationell strategi för utveckling av samhällets insatser till personer med psykiska sjukdomar och funktionshinder, SOU 2006:100.

Stryjan, Y. (1996) Systemskiftets irrgångar, Forskningsrapport 1996:1, Stockholm School of Business.

Stryjan, Y (2001) "Sweden: The Emergence of Work-Integration Social Enterprises" in Borzaga, C. \& Defourny, J. (eds) The Emergence of Social Enterprise, London and New York: Routledge.

Stryjan, Y. (2006) "Which place for social enterprises in a universal welfare state model?" in Nyssens, M. (ed.) Social Enterprise - At the crossroads of market, public policies and civil society, London and New York: Routledge.

Stryjan, Y. \& Wijkström, F. (1996) "Cooperatives and Nonprofits in Swedish Social Welfare", Annals of Public and Cooperative Economy, vol 67(1). 


\section{UNITED KINGDOM}

Roger Spear

\section{Use of the "social enterprise" brand and procurement practices}

The UK has used the brand or name of "social enterprise" in policy and development discourse for several years: in the UK context, this concept indeed fits with a number of political agendas. In a broad perspective it fits with the "Third way", promising to combine social justice with economic dynamism. It also fits with political agendas to reform public services towards an increase of contracting out practices by public authorities, and in such a context, it ought to be more acceptable to many stakeholders, including trade unions, than an increase of provision by for-profit providers.

However, progress here has been very segmented - social enterprises have developed in leisure services, homecare services, work integration, but they have not broken into procurement more widely. This is partly due to their size - as most social enterprises are small and medium organisations which will always face difficulties negotiating contracts. There is a political agenda to build capacity and professional operation of the voluntary and community sector (VCS) - whose more enterprise-like part may be considered social enterprises. Indeed, there is a strong focus in government policy on increasing the capacity of the voluntary sector for the provision of public services contracts. But despite these public efforts, using the brand is not yet what every social economy organisation wants or knows how to do, and the larger institutional players in the field (charities, and development and representative structures) are playing a more complex game of identity and resources.

\section{Social enterprise definitions and legal forms}

In terms of definitions of social enterprise, there are different ones operating in the UK. The EMES definition and that of Social Enterprise Coalition (SEC) have had some dissemination, but most influential has been the definition put forward by the Social Enterprise Unit, which states that:

Social enterprises are part of the growing "social economy". The social economy is a thriving and growing collection of organisations that exist between the traditional private sector on the one hand, and the public sector on the other. Sometimes referred to as the "'third sector", it includes voluntary and community organisations, foundations and associations of many types. A social enterprise is a business with primarily social objectives whose surpluses are principally reinvested for that purpose in the business or the community, rather than being driven by the need to maximise profit for shareholders and owners.

(Social Enterprise: A Strategy for Success)

\section{Major types of social enterprise and quantitative data}

The major types of social enterprises in the UK are traditional cooperatives/mutuals; social cooperatives; voluntary sector structures contracting for services and temporary/permanent employment; health/social care mutuals and voluntary organisations; community business for services and training/employment initiatives; social firms (providing mainly employment for learning disabled people); transitional employment enterprises; housing organisations; and sheltered workshops for disabled people.

Data from a Social Enterprise Unit survey ${ }^{28}$ helps provide a more accurate picture of the field of social enterprise. In 2005, there were 15,000 social enterprises in the $\mathrm{UK}^{29}$. They had a total turnover of $£ 18$ billions ( $€ 22.3$ billion), and a workforce of 775,000 people, including 300,000 volunteers ${ }^{30}$. As a benchmark, the figures of employment (1995) in the social economy (in FTEs) in the United Kingdom are the following: 127,575 jobs in cooperatives, 22,387 jobs in mutuals and 1,473,000 jobs in the voluntary sector, i.e. a total figure of 1,622,962 jobs (8.42\% of employment).

\footnotetext{
${ }^{28}$ Some elements of this survey are not reported with proper scientific rigour in the study; for example the workforce data were not expressed as FTEs.

${ }^{29}$ Based on legal structures typically used by social economy organisations: company limited by guarantee and industrial and provident societies.

${ }_{30}$ Volunteers work on average two hours/week; if we consider that other workers work full-time, the approximate figure in FTEs would be of 491,000.
} 


\section{Trends: charities as social enterprise}

The charity sector income increased by one billion pounds ( $€ 1.239$ billion) between 2003 and 2004, and for the last few years workforce has been increasing by 10,000 workers per year. There has been a 40 per cent increase in new charities between 1995 and 2005; large charities (i.e. those whose income exceeds one million pounds, i.e. $€ 1.239$ billion) have doubled in number, and we have seen the emergence of "super-charities", with recognised brands, and income over 100 million pounds (€ 123.9 billion).

Some interesting developments in this rapidly growing sector move charities more into the category of social enterprise. The dominant income source of charities has now become earned income ( 47 per cent); voluntary income represents 45 per cent, and investment income, 8 per cent. Figures also reveal an increasing trend for charities to engage in public sector contracting, and to a certain extent a "charitization" of public services (for example, there are now over 100 leisure trusts).

\section{Public policies and political changes}

There are no general public policies on which social enterprise can draw exclusively for their activities; for example, work integration subsidies are linked to disadvantaged individuals, rather than the enterprises supporting them. However there have been some (temporary) specific measures to support the development of the sector, such as finance for the Social Enterprise Unit, and a new programme for emerging health social enterprise.

Two major political changes occurred recently which affect the field of social enterprise. First, Government minister Patricia Hewitt, who was the minister of the Department of Trade and Industry, which had set up the Social Enterprise Unit, has moved to the Department of Health, and set up a new Social Enterprise Unit there, leading to the creation of specific support to social enterprises in this field. Secondly, the original Social Enterprise Unit has been transferred to the Office of the Third Sector (OTS), where it will link up with government responsibilities for the voluntary sector. This could be a major challenge for the social enterprise sector, since so far it has seemed that the large and medium-sized voluntary organisations have not always seen the virtue of subscribing to the social enterprise label, but this governmental transfer also allows the possibility for substantial coalition building with the voluntary sector.

\section{Research and theoretical preoccupations}

Most theoretical themes current in social enterprise discourse are no different from those in non-profit and cooperative literature. Nonetheless there appear to be a number of themes specific to social enterprise that preoccupy those researchers closest to the field. These themes map onto policy and practice preoccupations. The following appear significant, based on recent literature.

First, as the social enterprise sector grows and/or gets re-badged, there is considerable interest in mapping and studying the characteristics of the emerging subsectors. Notable examples are in the leisure sector (leisure trusts), in community recycling, and in the rapidly developing health sector.

Critiques of rhetoric, taking the form of discourse analyses of policy statements and media myths, constitute another significant theme. Such studies typically raise questions of isomorphism, sustainability and risk.

The governance arrangements in the UK are typically dominated by the extension of market relations into more and more spheres of activity. However, other dimensions that play a major part in the context of social enterprise are centrally imposed targets and management systems. There is a substantial body of work which attempts to develop appropriate management and measurement systems and performance indicators for social economy and social enterprise in particular, but at the same time develop a critical perspective on such systems, raising the question of whether there are standard, or isomorphic, ways in which social enterprises respond to external factors. 


\section{References}

Atkinson J, Tuohy S, Williams C. (2006) 2005 Survey of Social Enterprise. London: Small Business Unit URN 06/389, November 2006. Available at: http://www.berr.gov.uk/bbf/enterprisesmes/research-and-statistics/research-evaluation/business-surveys/page38370.html DTI (2002) Social Enterprises, A Strategy for Success. London: Department of Trade and Industry. Available at:

http://www.cabinetoffice.gov.uk/upload/assets/www.cabinetoffice.gov.uk/third_sector/se_strategy_20 02.pdf

IFF Research (2005) A Survey of Social Enterprise across the UK. London: Small Business Unit. Available at:

http://www.cabinetoffice.gov.uk/upload/assets/www.cabinetoffice.gov.uk/third_sector/survey_social_ enterprise_across_uk.pdf 
Appendix 1: The EMES definition of social enterprise

The EMES definition of social enterprise distinguishes between criteria that are more economic and indicators which are predominantly social.

To reflect the economic and entrepreneurial dimensions of initiatives, four criteria have been put forward:

\section{a) A continuous activity producing goods and/or selling services}

Social enterprises, unlike some traditional non-profit organisations, do not normally have advocacy activities or the redistribution of financial flows (as, for example, many foundations) as their major activity, but they are directly involved in the production of goods or the provision of services to people on a continuous basis. The productive activity thus represents the reason, or one of the main reasons, for the existence of social enterprises.

\section{b) A high degree of autonomy}

Social enterprises are created by a group of people on the basis of an autonomous project and they are governed by these people. They may depend on public subsidies but they are not managed, be it directly or indirectly, by public authorities or other organisations (federations, private firms etc.). They have both the right to take up their own position ("voice") and to terminate their activity ("exit").

\section{c) A significant level of economic risk}

Those who establish a social enterprise assume totally or partly the risk inherent in the initiative. Unlike most public institutions, their financial viability depends on the efforts of their members and workers to secure adequate resources.

\section{d) A minimum amount of paid work}

As in the case of most traditional non-profit organisations, social enterprises may also combine monetary and non-monetary resources, voluntary and paid workers. However, the activity carried out in social enterprises requires a minimum level of paid workers.

To encapsulate the social dimensions of the initiative, five criteria have been proposed:

\section{e) An explicit aim to benefit the community}

One of the principal aims of social enterprises is to serve the community or a specific group of people. In the same perspective, a feature of social enterprises is their desire to promote a sense of social responsibility at the local level.

\section{f) An initiative launched by a group of citizens}

Social enterprises are the result of collective dynamics involving people belonging to a community or to a group that shares a well-defined need or aim; this collective dimension must be maintained over time in one way or another, even though the importance of leadership - often embodied by an individual or a small group of leaders - must not be neglected.

\section{g) A decision-making power not based on capital ownership}

This criterion generally refers to the principle of "one member, one vote" or at least to a decisionmaking process in which voting power is not distributed according to capital shares on the governing body which has the ultimate decision-making rights. Moreover, although the owners of the registered capital are important, the decision-making rights are generally shared with the other stakeholders.

\section{h) A participatory nature, which involves various parties affected by the activity}

Representation and participation of users or customers, influence of various stakeholders on decision-making and a participative management are often important characteristics of social 
enterprises. In many cases, one of the aims of social enterprises is to further democracy at the local level through economic activity.

\section{i) A limited profit distribution}

Social enterprises not only include organisations that are characterised by a total non-distribution constraint, but also organisations which - like cooperatives in many countries - may distribute profits, but only to a limited extent, thus allowing to avoid a profit-maximising behaviour.

Source: First EMES research project, as introduced by Defourny, J. (2001) "Introduction: from third sector to social enterprise", in Borzaga, C. \& Defourny, J. (eds) The Emergence of Social Enterprise, London and New York: Routledge (pp. 16-18). 


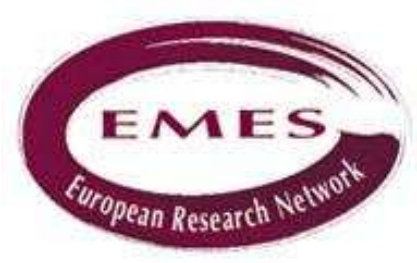

\section{Publications of the EMES Network}

\section{Books}

Borzaga, C. \& Defourny, J. (eds.) (2001), The Emergence of Social Enterprise, Routledge, London, $386 \mathrm{p}$.

Spear, R., Defourny, J., Favreau, L. \& Laville, J.-L. (eds.) (2001), Tackling Social Exclusion in Europe. The Contribution of the Social Economy, Ashgate, Aldershot, 359p.

Evers, A. \& Laville, J.-L. (eds.) (2004), The Third Sector in Europe, Edward Elgar, Cheltenham, 288p.

Borzaga, C. \& Spear, R. (eds.) Trends and Challenges for Co-operatives and Social Enterprises in Developed and Transition Countries, Edizioni31, 2004, 280 p.

Nyssens, M. (ed) (2006) Social Enterprise. At the crossroads of market, public policies and civil society, Londres et New York: Routledge, 386p.

Laville, J.-L. \& Cattani, A.D. (eds) (2005) Dictionnaire de l'autre économie, Paris: Desclée de Brouwer, 564p.

\section{Working Papers relating to the "PERSE" Project}

Eme, B. \& Gardin, L. (2002) "Les entreprises sociales d'insertion par le travail en France. Tendances et enjeux", EMES Working Papers, no. 02/01.

Borzaga, C. \& Loss, M. (2002) "Work Integration Social Enterprises in Italy. Trends and Issues", EMES Working Papers, no. 02/02.

Nyssens, M. \& Grégoire, O. (2002) "Les entreprises sociales d'insertion par le travail en Belgique. Tendances et enjeux", EMES Working Papers, no. 02/03.

Bode, I., Evers, A. \& Schulz, A. (2002) "Work Integration Social Enterprises in Germany. Trends and Issues", EMES Working Papers, no. 02/04.

Davister, C., Defourny, J. \& Grégoire, O. (2003) "Les entreprises sociales d'insertion dans l'union européenne. Un aperçu général", EMES Working Papers, no. 03/11. (Also available in English: EMES Working Papers, no. 04/04.

Stryjan, Y. (2004) "Work Integration Social Enterprises in Sweden", EMES Working Papers, no. $04 / 02$

O'Hara, P. \& O'Shaughnessy, M. (2004) "Work Integration Social Enterprises in Ireland", EMES Working Papers, no. 04/03.

Vidal, I. \& Claver, N. (2004) "Work Integration Social Enterprises in Spain”, EMES Working Papers, no. $04 / 05$.

Perista, H. \& Nogueira, S. (2004) "Work Integration Social Enterprises in Portugal”, EMES Working Papers, no. 04/06.

Pättiniemi, P. (2004) "Work Integration Social Enterprises in Finland", EMES Working Papers, no. 04/07.

Hulgård, L. \& Bisballe, T. (2004) "Work Integration Social Enterprises in Denmark”, EMES Working Papers, no. 04/08. 


\section{Working Papers related to the "ELEXIES" Project}

O'Shaughnessy, M. (2002) "National Profiles of Work Integration Social Enterprises: Ireland", EMES Working Papers, no. 02/05.

Spear, R. (2002) "National Profiles of Work Integration Social Enterprises : United Kingdom", EMES Working Papers, no. 02/06.

Eme, B. \& Gardin, L. (2002), "Profils nationaux des entreprises sociales d'insertion : France", EMES Working Papers, no. 02/07.

Laurelii, E. \& Stryjan, Y. (2002) "National Profiles of Work Integration Social Enterprises: Sweden", EMES Working Papers, no. 02/08.

Perista, H. \& Nogueira, S. (2002) "National Profiles of Work Integration Social Enterprises: Portugal", EMES Working Papers, no. 02/09.

Pättiniemi, P. \& Immonen, N. (2002) "National Profiles of Work Integration Social Enterprises: Finland", EMES Working Papers, no. 02/10.

Vidal Martinez, I. \& Valls Jubany, C. (2003) "National Profiles of Work Integration Social Enterprises: Spain", EMES Working Papers, no.03/01.

Delaunois, P. (2003) "Profils nationaux des entreprises sociales d'insertion : Luxembourg", EMES Working Papers, no. 03/02.

Grégoire, O. (2003) "Profils nationaux des entreprises sociales d'insertion : Belgique", EMES Working Papers, no. 03/03.

Loss, M. (2003) "National Profiles of Work Integration Social Enterprises: Italy", EMES Working Papers, no. 03/04.

Schulz, A. (2003) "National Profiles of Work Integration Social Enterprises: Germany", EMES Working Papers, no. 03/05.

Gruber, C. (2003) "National Profiles of Work Integration Social Enterprises: Austria", EMES Working Papers, no. 03/06.

Delaunois, P. (2003) "National Profiles of Work Integration Social Enterprises: Luxembourg", EMES Working Papers, no. 03/07.

Grégoire, O. (2003) "National Profiles of Work Integration Social Enterprises: Belgium", EMES Working Papers, no. 03/08.

Eme, B. \& Gardin, L. (2003) " National Profiles of Work Integration Social Enterprises: France", EMES Working Papers, no. 03/09.

Spear, R. \& Bidet, E. (2003) "The Role of Social Enterprise in European Labour Markets", EMES Working Papers, no. 03/10. (Also available in French: EMES Working Papers no. 04/01)

\section{Autres Working Papers de la série EMES}

Fraisse, L., Lhuillier, V. \& Petrella, F. (2007) "Une proposition de typologie des régimes de gouvernance à partir des évolutions observées dans les services d'accueil des jeunes enfants en Europe", Working Papers Series, no. 07/01, Liège: EMES European Research Network.

Defourny, J. \& Nyssens, M. (eds.) (2008) "Social Enterprise in Europe: Recent Trends and Developments", Working Papers Series, no. 08/01, Liège: EMES European Research Network.

All these papers are available

in electronic form on www.emes.net

in paper form at EMES European Research Network

Sart Tilman, B33, Box 4 - University of Liège 4000 Liège - Belgium

Price: $3 €$ (all fees included) 